PRZEGLĄD NAUK HISTORYCZNYCH 2016, R. XV, NR 1

http://dx.doi.org/10.18778/1644-857X.15.01.02

PIOTR RoBAK

(UNIWERSYTET ŁóDZKI)*

\title{
Angielski handel zewnętrzny (i kolonialny) w dobie wojny o imperium (1740-1765)
}

Streszczenie. Artykuł prezentuje rozwój angielskiego handlu zewnętrznego (i kolonialnego) w okresie dwóch kontynentalnych konfliktów zbrojnych, toczonych także na morzach i w koloniach, w które zaangażowana była Wielka Brytania w latach 1739-1763. Zaprezentowana analiza tego handlu została oparta na szacunkowych danych statystycznych za lata 1740-1765 (stąd ramy chronologiczne artykułu) i przeprowadzona w odniesieniu do dwóch głównych obszarów multilateralnej wymiany: europejskiej i oceanicznej, w tym kolonialnej. $Z$ poczynionych przez Autora ustaleń wynika, że rynki europejskie utrzymały dominująca pozycję $\mathrm{w}$ angielskim handlu zewnętrznym w omawianym okresie, choć rozwijały się w sposób zróżnicowany regionalnie i w ogólnym dodatnim bilansie mniej dynamicznie niż na rynkach zamorskich (i kolonialnych). Te bowiem, rozłożone na obszarach: atlantyckim i azjatyckim, odnotowały istotny wzrost wartości i wielkości wymiany, zwłaszcza w odniesieniu do rynków amerykańskich (Ameryka Północna i Indie Zachodnie), mimo że w ogólnym bilansie zachowały stały charakter deficytowy. Jednakże oceaniczny (i kolonialny) import decydował w dużej mierze o rosnacym europejskim reeksporcie angielskiego handlu zewnętrznego, pozwalając mu utrzymać stały dodatni bilans handlowy we wspomnianych latach. Na powyższe zróżnicowanie wielkości i dynamiki rozwoju angielskiego handlu zewnętrznego miały oczywisty, choć nie wyłączny, wpływ toczące się długotrwałe zmagania wojenne. $\mathrm{Na}$ niektórych rynkach europejskich (zwłaszcza euroatlantyckim i lewantyńskim) przyniosły one widoczny regres obrotów, natomiast w sferze pozaeuropejskiej okazały się często czynnikiem sprzyjającym intensyfikacji wymiany handlowej, co niewattpliwie było efektem brytyjskiej dominacji zbrojnej na morzach i w koloniach. Ta sytuacja ukształtowała w pewnej mierze przekonanie brytyjskich merkantylistów i polityków, głównie od lat pięćdziesiątych XVIII w., że wojna służy rozwojowi angielskiego handlu zamorskiego.

Słowa kluczowe: Anglia, handel zagraniczny, kolonizacja, XVIII wiek.

\footnotetext{
* Wydział Filozoficzno-Historyczny, Instytut Historii, Katedra Historii Nowożytnej.
} 
$\mathrm{P}$ o podpisaniu traktatów w Utrechcie (1713) Wielka Brytania wykorzystała czas względnego dla niej pokoju w stosunkach międzynarodowych w Europie ${ }^{1}$ na dalszy wzrost handlu zewnętrznego, w tym kolonialnego, którego rozkwit pobudziła tzw. rewolucja handlowa w drugiej połowie XVII w. ${ }^{2}$ Od tego czasu najdynamiczniej rozwijał się angielski handel zamorski na zachodniej półkuli, zarówno w brytyjskich koloniach, jak i po 1713 r., w ograniczonym stopniu (głównie kontrabandy), w zmonopolizowanym obszarze handlu iberoamerykańskiego. Procesowi stopniowej amerykanizacji handlu pozaeuropejskiego towarzyszył wzrost tonażu brytyjskiej floty handlowej ${ }^{3}$.

Tymczasem w 1739 r. Wielka Brytania rozpoczęła „wojnę o handel" z Hiszpania, w gruncie rzeczy o utrzymanie ograniczonego dostępu do hispanoamerykańskich portów, która przerodziła się w następnych latach, zbiegajac się $z$ dwoma dużymi konfliktami zbrojnymi w Europie, toczacymi się także na morzach i w koloniach, w długotrwałe zmagania o dominację na terytoriach pozaeuropejskich. Podstawowe znaczenie dla tej konfrontacji miała, siegajaca początków XVIII stulecia, rywalizacja dworów burbońskich z brytyjska monarchia. Sukces w tej batalii odniosła w 1763 r. Wielka Brytania. W pierwszym rzędzie zawdzięczała go zwycięskim operacjom Królewskiej Marynarki i kampaniom wojsk działajacych w koloniach, determinacji ich dowódców i części polityków, na czele $z$ Williamem Pittem starszym, oraz sprawnemu finansowaniu wojny. Dzięki temu Wielka Brytania uzyskała nie tylko rozległe

${ }^{1}$ Od 1715 r. brytyjska flota wojenna ograniczyła swój udział w Wielkiej Wojnie Północnej (do 1721 r.). Z kolei w latach 1718-1719 i 1727-1728 zaangażowana była w wojnie $z$ Hiszpanią. Natomiast Wielka Brytania zachowała neutralność w wojnie o sukcesję polską (1733-1738), mimo że był to wówczas największy konflikt w Europie. Szerzej na ten temat: J. Black, A System of Ambition? British Foreign Policy 1660-1793, Oxford 1991, s. 150-158; D. M c Kay, H.M. S c ott, The Rise of the Great Powers 1648-1815, London-New York 1983, s. 87-91, 131 i 145-154; J.L. Sutton, Wojna o sukcesje polska 1733-1735, Oświęcim 2015, s. 23-25, 40-41, 188-202.

2 Termin „rewolucja handlowa”, odwołując się do pojęcia użytego w $1770 \mathrm{r}$. przez abbé G.T. Raynala, utrwalił się w literaturze przedmiotu w odniesieniu do Anglii drugiej połowy XVII w. R. Davis, A Commercial Revolution. English Overseas Trade in the Seventeenth and Eighteenth Centuries, London 1967, s. 9 i n. Por. też G. Holmes, The Making of a Great Power. Late Stuart and Early Georgian Britain, Oxford 1993, s. 62-67.

${ }^{3}$ I d e m, D. Se chi, The Age of Oligarchy. Preindustrial Britain 1722-1783, London-New York 1993, s. 154 i 379; F. O' Gorm a n, British Political and Social History 1688-1832, London-New York 1997, s. 177. 
imperium kolonialne w Ameryce Północnej, lecz także dominująca pozycję w Indiach Wschodnich, a przede wszystkim panowanie na morzach ${ }^{4}$.

Celem artykułu, stanowiącego kontynuację podjętej wcześniej przez autora problematyki ${ }^{5}$, jest przedstawienie zasadniczych kierunków rozwoju poszczególnych sektorów angielskiego (i walijskiego) ${ }^{6}$ handlu zewnętrznego, rozłożonego na wiele rynków, w dobie

${ }^{4} \mathrm{Na}$ brytyjsko-hiszpański konflikt nałożyła się wojna o sukcesję austriacka (1740-1748). Kończący ją pokój w Akwizgranie nie przyniósł nabytków kolonialnych żadnej ze stron konfliktu ani nie zakończył sporów na obszarach pozaeuropejskich. Działania zbrojne toczyły się nadal w Indiach Wschodnich (do 1754 r.), by przenieść się, po ich chwilowym zawieszeniu, do Doliny Ohio w Ameryce Północnej. Te zatargi kolonialne stały się też przyczyna wybuchu w $1756 \mathrm{r}$. wojny brytyjsko-francuskiej, która zbiegła się w tym samym roku z europejską wojną siedmioletnią. Konflikt burbońsko-brytyjski zakończył pokój paryski (10 II 1763 r.). Sankcjonował on większość brytyjskich zdobyczy kolonialnych (Kanadę, zachodnia Luizjanę, Florydę, kilka wysp w archipelagu Małych Antyli i faktorii w Senegambii i w Indiach Wschodnich), czyli jednocześnie przeważająca pozycję Wielkiej Brytanii na obszarze pozaeuropejskim, co tym bardziej było odczuwalne wobec jednoczesnego rozpadu francuskiego imperium kolonialnego w Ameryce Północnej i osłabienia jego pozycji w Indiach Wschodnich oraz porażce Hiszpanii sprzymierzonej $z$ Wersalem. Ogólnie na temat wydarzeń $z$ lat 1740-1763 m.in. por. J.P. Bois, De la paix des rois à l'ordre des empereurs 1714-1815, Paris 2003, s. 152-199; D. McKay, H.M. Scott, op. cit., s. 159-200; F.A.J. Szabo, Wojna siedmioletnia $w$ Europie 1756-1763, Oświęcim 2014. W odniesieniu do konfliktów burbońsko-brytyjskich m.in. por. M. Antoine, Louis XV, Paris 1989, s. 354-403, 668-685, 731-753 i 800-813; J. Black, op. cit., s. 150-203; ide m, Natural and Necessary Enemies. Anglo-French Relations in the Eighteenth Century, London 1986, s. 36-63; R. Harding, Seapower and Naval Warfare, 1650-1830, London 1999, s. 192-218; G. Holmes, D. Szechi, op. cit., s. 55-67 i 252-266; G. Niedhart, Handel und Krieg in der Britischen Weltpolitik 1738-1763, München 1979, s. 24-140; R. Pares, American versus Continental Warfare, 1739-1763, „English Historical Review" 1936, vol. LI, s. 429-465; M. S ave11e, The Diplomatic History of the Canadian Boundary 1749-1763, New Haven-Toronto 1940, s. 144-146.

${ }^{5}$ P. Robak, Angielski handel zewnętrzny (i kolonialny) w latach 1715-1740. Amerykanizacja rynku pozaeuropejskiego, „Przegląd Nauk Historycznych” 2013, R. XII, nr 2, s. 41-70.

${ }^{6}$ Statystyki szkockiego handlu (w postaci względnie uporządkowanej) dostępne sa dopiero od $1755 \mathrm{r}$. Zawarte w nich rejestry pozwalaja stwierdzić, że handel szkocki stanowił zaledwie 5\% wartości handlu angielskiego. Poza tym duża część szkockich towarów była wysyłana do Londynu na reeksport i stąd pośrednio znajdowała miejsce w angielskich statystykach handlowych. Powyższe uwagi powodują, że te ostatnie zestawienia właściwie można traktować jako brytyjskie (choć Irlandia występuje w nich samodzielnie w strefie handlu zewnętrznego Wysp Brytyjskich). R. Davis, English Foreign Trade, 1700-1774, "The Economic History Review" [dalej: EcHR] 1962, vol. XV, No. 2, s. 285-286; G. Holmes, D. Szechi, op. cit., s. 153 . 
brytyjskiego udziału we wspomnianych wojnach. Ze względu na podjęty problem badawczy takie podejście do zagadnienia odbiega od ogólnie przyjętej metodologii badań rozwoju handlu nowożytnego, w tym angielskiego, która w długofalowej analizie zachodzacych w nim zmian zazwyczaj skupiała się na latach pokoju ${ }^{7}$. Poza tym zaprezentowane przez autora omówienie rozwoju poszczególnych rynków angielskiego handlu zewnętrznego uwzględnia przede wszystkim wartości i dynamikę dokonywanych na nich obrotów handlowych, a nie ich wielkość towarową. Nie stanowi zatem typowego ujęcia funkcjonalnego. Takie podejście podyktowane zostało głównie doborem informacji statystycznych. Jednak zachowane rejestry handlowe, odnoszące się do XVIII w. (jak i czasów wcześniejszych), zawierają w większości tylko orientacyjne dane, niepozbawione wielu błędów i nieścisłości ${ }^{8}$. Stąd wyłaniający się z nich obraz angielskiego handlu zewnętrznego w latach 1740-1765 nie oddaje

7 Ralph Davis, przeprowadzając analizę angielskiego handlu, odniósł się tylko do lat pokoju (jako najbardziej reprezentatywnych). Idem, English Foreign Trade..., s. 285-303. Do ustaleń tego historyka odwołał się G. Niedhart, op. cit., s. 60-61. Podobna periodyzację przyjęli też: D.C. Coleman, The Economy of England 1450-1750, Oxford 1978, s. 133, 138-140 i 143; P. Deane, The First Industrial Revolution, Cambridge 1969, s. 56; G. Holmes, D. Szechi, op. cit., s. 380. W polskiej historiografii zbliżony podział przyją A. M ączak, U źródeł nowoczesnej gospodarki europejskiej, Warszawa 1967, s. 72-73. Inni historycy stosuja podział omawianego okresu na przedziały dziesięcioletnie: R. Brown, Society and Economy in Modern Britain, 1700-1850, New York 1991, s. 163-165; B.R. Mitche11, P. Deane, Abstract of British Historical Statistics, Cambridge 1962, s. 279-283.

${ }^{8}$ Oszacowanie wartości angielskiego handlu w XVIII w. nastręcza szereg trudności. W ówczesnych statystykach handlowych, sporządzonych na podstawie rejestru dochodów (pochodzacych głównie $z$ Inspector General's Return znajdujacych się w Public Record Office), nie brano pod uwagę aktualnych cen importu i eksportu, ale oficjalne ceny z końca XVII w. To ograniczenie nie dotyczyło cen na nowe towary (głównie kolonialne). Te rejestrowane były po cenach wówczas obowiązujących. Wreszcie angielskie statystyki handlowe nie uwzględniaja, z przyczyn oczywistych, olbrzymiej ówczesnej kontrabandy. Zestawienia wartości obrotów handlowych dokonane przez E.B. S ch u m peter a (English Overseas Trade Statistics, 1697-1808, Oxford 1960, s. 16-18) uważane są za najbardziej szczegółowe i na nich oparty został ten artykuł. Por. T.S. As h to n, Introduction, [w:] E.B. Schu mpeter, op. cit., s. 1-9; T.S. A s h to n, An Economic History of England: the $18^{\text {th }}$ Century, London 1955, s. 150-154; D.C. Coleman, op. cit., s. 134-135; Ph. Deane, op. cit., s. 60. Podobne statystyki angielskiego handlu zewnętrznego (w tym kolonialnego) dla pierwszej połowy XVIII w. zamieszczaja też inni autorzy: R. B rown, op. cit., s. 163; R. Davis, English Foreign Trade..., s. 292 i 300-303; Ph. De a ne, W.A. Cole, British Economic Growth 1688-1959, Cambridge 1967, tab. 22 (a za nimi G. Holmes, D. Szechi, op. cit., s. 380). 
w pełni faktycznej wielkości i złożoności jego rozwoju, a stanowi jedynie analizę występujących w nim podstawowych tendencji ${ }^{9}$.

Przyjęty dobór informacji statystycznych wyznaczył również ramy chronologiczne artykułu, które w przybliżonym stopniu pokrywaja się ze wzmiankowanymi wydarzeniami politycznymi i militarnymi.

\section{BILANS OTWARCIA}

\section{Angielski handel zewnętrzny (i kolonialny) w latach 1715-1740 Kierunki rozwoju}

Po pokoju w Utrechcie Wielka Brytania kontynuowała podstawowe kierunki rozwoju multilateralnego handlu europejskiego i oceanicznego, jakie ukształtowały się już w drugiej połowie XVII wieku, zatem w początkach wspomnianej „rewolucji handlowej” ${ }^{10}$. W dobie Restauracji Stuartów należało do nich przede wszystkim utrzymanie dominującej pozycji handlu europejskiego w całym handlu zewnętrznym $z$ jednoczesnym spadkiem eksportu towarów wełnianych, głównie na rynek zachodnioeuropejski, na rzecz stopniowo rosnącego na nim reeksportu importowanych towarów kolonialnych. Napływ tych towarów był jednym $z$ efektów rozwijającego się dalekosiężnego handlu pozaeuropejskiego, głównie na wielu szlakach atlantyckich, łączacych wielostronna wymianę handlową (na wzór portugalski, a potem holenderski) ${ }^{11}$ na trzech kontynentach.

${ }^{9} \mathrm{~W}$ ten sposób zagadnienie to było często interpretowane w anglosaskiej literaturze przedmiotu. Wykaz ważniejszych publikacji omawiajacych ten temat do 1740 r. w: P. Robak, op. cit., s. 43 (przyp. 5). Natomiast warto w tym miejscu uzupełnić bibliografię tej problematyki o kilka kolejnych studiów: M. B erg, In Pursuit of Luxory: Global History and British Consumer Goods in the Eighteenth Century, "Past and Present” 2004, No. 182, s. 85-142; T. Brinley, The Industrial Revolution and the Atlantic Economy: Selected Essays, New York 1993, s. 34-46; S. Conway, War, State, and Society in Mid-Eighteenth-Century Britain and Ireland, Oxford 2006, s. 100-108; C.K. Harley, Trade: Discovery, Mercantilism and Technology, [w:] The Cambridge Economic History of Modern Britain, vol. I (Industralisation, 1700-1860), eds R. Floud, P. Johnson, Cambridge 2004, s. 175-187; N.F. Ko e hn, The Power of Commerce: Economy and Governance in the First British Empire, Ithaca-New York 1994, s. 1-24.

${ }^{10} \mathrm{Na}$ temat miejsca i roli tego zjawiska w preindustrialnych gospodarkach państw euroatlantyckich por. P. Ro b a k, op. cit., s. 43-50 (tu też literatura tego zagadnienia).

${ }^{11} \mathrm{Na}$ temat tych odniesień por. M. Małowist, Europa $i$ jej ekspansja XIV-XVII w., Warszawa 1993, s. 186-202 i 234-254; B. Nowak, Afryka w gospodarce światowej XVI-XVII wieku, [w:] Europa i świat w poczatkach epoki nowożytnej, cz. 1 (Społeczeństwo, kultura, ekspansja), red. A. Mączak, Warszawa 1991, s. 301-318; N. F ergu s o n, Imperium. Jak Wielka Brytania zbudowała nowoczesny 
W ten sposób tworzyły się podstawy tzw. atlantyckiej gospodarki Anglii, która jednak w strukturze wymiany okazała się trwale deficytowa ${ }^{12}$. Mimo to właśnie zamorski handel, sięgający również portów azjatyckich, dzięki dużemu udziałowi w reeksporcie, w dużej mierze decydował o dodatnim bilansie całego angielskiego handlu zewnętrznego ${ }^{13}$.

Powyższych kierunków rozwoju multilateralnej wymiany handlowej nie zmienił udział Anglii w wojnie o sukcesję hiszpańska (1701-1713). Natomiast pokazał on, że sukcesy militarne, odnoszone w Europie i w koloniach, sankcjonowane potem traktatami pokojowymi oraz wsparte silna pozycja na morzach, otwierały drogę do zyskania nowych rynków handlowych, postrzeganych przez ówczesnych teoretyków merkantylizmu jako istotna perspektywa pomnożenia bogactwa Anglii ${ }^{14}$. Wkroczenie na nowe rynki nie musiało też pociagać za sobą konieczności zdobywania kolejnych terytoriów zamorskich. Trafnie wyraził to w 1707 r. Daniel Defoe, kiedy napisał: „nie chcemy posiadać więcej krajów niż mamy [...], chcemy otwartego i wolnego handlu $z$ nimi" ${ }^{15}$. Tak narodziła się koncepcja tzw. nieformalnego imperium (informal empire), której urzeczywistnieniem był ograniczony dostęp brytyjskich inwestorów, kupców i żeglarzy (w formie zinstytucjonalizowanej i w postaci kontrabandy) do zmonopolizowanej strefy handlu iberyjskiego w Europie i w Ameryce Południowej ${ }^{16}$.

Angielski handel zewnętrzny (i kolonialny), zwłaszcza atlantycki, korzystał zatem po 1713 r. z osiagniętej przez Wielką Brytanię pozycji mocarstwa morskiego. Analiza jego rozwoju, mimo że

świat, Warszawa 2007, s. 37-52; H. Zin s, Kupcy i kidnaperzy. Handel niewolnikami w dziejach Afryki i Ameryki, Lublin 1999, s. 49-59.

12 Ze względu na przewage importu nad eksportem/reeksportem. T. Brinley, op. cit., s. 34-36; R. Brown, op. cit., s. 160-171; C.K. Harley, op. cit., vol. I, s. 181-203; P. Robak, op. cit., s. 60-61.

13 Szerzej to zagadnienie omawia R. Davis, English Foreign Trade..., s. 300. Por.też dane dla angielskiego reeksportu: E.B. Schu m peter, op. cit., s. 15.

14 Pozyskanie nowego rynku, jak zauważył Daniel Defoe w 1728 r., stawało się wyłączna miarą sukcesu gospodarczego Anglii. D.C. Cole man, op. cit., s. 131. Na temat poglądów angielskich merkantylistów w końcu XVII i w początkach XVIII w. por. D. Armitage, The Ideological Origins of the British Empire, Cambridge 2000, s. 166; K.E. Knorr, British Colonial Theories 1570-1850, Toronto 1944, s. 95-98 i 102-104; L. Magnu s o m, Mercantilism: The Shaping of an Economic Language, New York 1994, s. 152-154.

15 Cyt. za: D.A. Baugh, Maritime Strenght and Atlantic Commerce. The Uses of „a Grand Marine Empire”, [w:] An Imperial State at War. Britain from 1689 to 1815, ed. L. Stone, London-New York 1994, s. 201.

${ }^{16}$ Ibidem. Por. też J. Bla ck, A System of Ambition..., s. 94-95. 
przeprowadzona na podstawie szacunkowych danych statystycznych (bez wliczenia dochodów $z$ kontrabandy), pozwala jednak na charakterystykę zachodzacych w nim zasadniczych procesów.

Handel ten, podobnie jak w drugiej połowie XVII w., odnotował ogólny wzrost obrotów towarowo-pieniężnych (o 27\%). Ciagle najważniejszym dla niego rynkiem była kontynentalna Europa (wzrost o 20\%), w szczególności zachodnia i kraje iberyjskie, choć w coraz większym stopniu dochodziły też do głosu państwa północne i wschodnie (tu głównie deficytowy import $z$ Rosji). Natomiast najszybszy wzrost tego handlu nastapił w strefie pozaeuropejskiej (o 46\%). W strukturze tego handlu zdecydowana przewage co do wartości obrotów towarowych uzyskał rynek atlantycki nad azjatyckim (75\% do 25\%), z takim samym tempem rozwoju (o 46\%). Ugruntowywało to pierwszoplanowa rolę wspomnianej „atlantyckiej gospodarki" i związane $z$ nim zjawisko amerykanizacji handlu dalekosiężnego ${ }^{17}$. Poza tym dynamiczny rozwój handlu pozaeuropejskiego, tworzacego coraz bardziej skomplikowana globalna sieć wymiany, łącząca rynki wszystkich ówcześnie znanych kontynentów $z$ centrum w Londynie, mimo że sam deficytowy ( $z$ wyjątkiem rynku północnoamerykańskiego i afrykańskiego), decydował w przeważającej mierze o uzyskaniu przez Wielka Brytanię dodatniego bilansu w całym handlu zewnętrznym. Wynikało to $z$ istotnego udziału importu oceanicznego (w tym kolonialnego) w reeksporcie na Starym Kontynencie, co pozwalało handlowi europejskiemu uzyskać nie tylko dodatni bilans, lecz także utrzymać pierwszorzędną pozycję pod względem wielkości obrotów w angielskim handlu zewnętrznym.

W omawianym okresie nastapiły też zmiany w instytucjonalnej organizacji tego handlu. Widoczne to było zwłaszcza w „gospodarce atlantyckiej”, w której postępowało ograniczanie monopolu kompanii kupieckich, w większości powstałych jeszcze w XVII w., na rzecz rozszerzającej się strefy wolnego handlu (zwłaszcza niewolniczego), choć ujętego ciagle w ramy merkantylnego ustawodawstwa ${ }^{18}$.

${ }^{17}$ Pojęcie to wprowadził do literatury przedmiotu W. Shlote. Por. id e m, British Overseas Trade from 1700 to the 1930s, Oxford 1952, s. 79. Por. też T. Brinley, op. cit., s. 36; D.A. Farnie, The Commercial Empire of the Atlantic, 1607-1783, EcHR 1962, vol. XV, No. 2, s. 212-214.

18 Powyższe uwagi stanowia uogólnienie rozważań autora zawartych w: P. Robak, op. cit., s. 50-69 (tu też literatura przedmiotu). 


\section{HANDEL ZEWNĘTRZNY W LATACH 1740-1765 Statystyka, struktura, towary}

Zaprezentowany okres funkcjonowania angielskiego handlu zewnętrznego (i kolonialnego) przebiegał w zupełnie innej sytuacji międzynarodowej niż ten w następnym ćwierćwieczu. Był to bowiem wspomniany czas konfliktów zbrojnych toczonych na szerszą niż dotychczas skalę, $z$ udziałem większej liczby wojska i floty wojennej oraz przeznaczonych na ich utrzymanie środków finansowych. Poza tym na obszarze pozaeuropejskim (od Indii Wschodnich po wybrzeża afrykańskie, amerykańskie, posiadłości na Karaibach i wreszcie wody trzech oceanów) rywalizacja ta nabrała niemal permanentnego charakteru, angażując również na dużą skalę społeczności kolonialne ${ }^{19}$.

Tabela 1

Angielski handel zewnętrzny (i kolonialny) w latach 1741-1765 (w tys. £)

\begin{tabular}{|l|c|c|c|c|c|}
\hline \multicolumn{1}{|c|}{ Lata } & $1741-1745$ & $1746-1750$ & $1751-1755$ & $1756-1760$ & $1761-1765$ \\
\hline Import & 7168 & 7224 & 8133 & 8325 & 10025 \\
\hline $\begin{array}{l}\text { Eksport/ } \\
\text { reeksport }\end{array}$ & 9493 & 11152 & 12785 & 12153 & 14436 \\
\hline Łacznie & 16661 & 18376 & 20918 & 20478 & 24461 \\
\hline
\end{tabular}

Źródło: E.B. Schumpeter, English Overseas Trade Statistics, 1697-1808, Oxford 1960, s. $17-18^{20}$.

${ }^{19}$ W okresie 1740-1765 brytyjska flota wojenna zwiększyła liczbę okrętów z 154 do 266 (w tym 38 dodatkowych liniowców). Na temat wielkości tej floty i jej operacji morskich por. R. Harding, op. cit., s. 192-218 i 291; P. Wieczorkiew i c z, Historia wojen morskich, t. I (Wiek żagla), Londyn 1995, s. 22-23 i 273-332. Koszty ówczesnych wojen (w tym wielkości i udziału w nich całych brytyjskich sił militarnych) przedstawiaja: M.S. Anderson, War and Society in Europe of the Old Regime 1618-1789, London 1998, s. 162-165 i J. Brewer, The Sinews of Power. War, Money and the English State, 1688-1783, London 1989, s. 21-42 i 174-177. O udziale społeczności kolonialnych we wspomnianych wojnach por. J.L. Rutledge, Century of Conflict: The Straggle Between the French and British in Colonial America, New York 1956; B.W. Sh e e han, Wojny imperialne, [w:] Historia Stanów Zjednoczonych Ameryki, t. I (1607-1763), red. M.J. Rozbicki i I. Wawrzyczek, Warszawa 1995, s. 304-321

${ }^{20}$ Por. też R. Brown, op. cit., s. 162; D.C. Coleman, op. cit., s. 134-135; Ph. Deane, op. cit., s. 60. 
Ta sytuacja rodziła poważne zagrożenia co do trwałości dotychczasowych kierunków rozwoju angielskiego handlu zewnętrznego, dynamiki jego wzrostu (głównie w odniesieniu do pozaeuropejskiego handlu), a także wielkości obrotów handlowych na poszczególnych rynkach.

Odpowiedzi na te dylematy w analizowanym okresie udziela w pierwszym rzędzie statystyka obrotów handlowych: całkowitych i $z$ podziałem na poszczególne rynki. Oparte na niej oszacowane wartości ogólnego wzrostu angielskiego handlu i jego dynamiki przedstawiaja sąsiednie tabele (1 i 2 ).

Tabela 2

Dynamika wzrostu angielskiego handlu zewnętrznego w latach 1741-1765 (w \%)

\begin{tabular}{|l|c|c|c|c|c|}
\hline \multicolumn{1}{|c|}{ Lata } & $1741-1745$ & $1746-1750$ & $1751-1755$ & $1756-1760$ & $1761-1765$ \\
\hline Import & 100 & 100 & 113 & 116 & 140 \\
\hline $\begin{array}{l}\text { Eksport/ } \\
\text { reeksport }\end{array}$ & 100 & 117 & 135 & 128 & 150 \\
\hline Eacznie & 100 & 110 & 125 & 123 & 147 \\
\hline
\end{tabular}

Źródło: obliczenia własne na podstawie tabeli 1.

Z zamieszczonych danych statystycznych wynika, że w badanym okresie ogólny wzrost całego angielskiego handlu zewnętrznego wynosił 47\% (7,8 mln £). Rozwój importu sięgnął 40\%, eksportu/ reeksportu zaś $50 \%$. Średnio reeksport stanowił $1 / 3$ całego eksportu $^{21}$, co pozwoliło zachować stały dodatni bilans handlowy analizowanych obrotów. Najbardziej dynamiczny wzrost handlu zewnętrznego nastąpił w latach 1751-1756 i na początku lat sześćdziesiątych, zwłaszcza w odniesieniu do poprzednich okresów: 1746-1750 i 1756-1760 (całego handlu o 15\% i 19\%, wwozu o 13\% i $20 \%$ oraz wywozu o $18 \%$ i $19 \%$ ).

Priorytetowym towarem importowym były artykuły żywnościowe, przede wszystkim cukier, potem tytoń, wina, herbata, owoce, ryż, pieprz, kawa, leki ziołowe. W dalszej kolejności występował

${ }^{21}$ Wielkość reeksportu na podstawie obliczeń E.B. Schumpeter, op. cit., s. 15. Por. R. Davis, English Foreign Trade..., s. 302-303. 
import surowców, takich jak: jedwab, len i konopie, bawełna, przędza, barwniki, żelazo, drewno, olej, łój czy skóry. Na końcu importowanych towarów pojawiały się produkty manufakturowe: wyroby płócienne, perkal, jedwab, artykuły metalowe.

Odmiennie sprawa przedstawiała się $z$ eksportem (przeważnie brytyjskiej produkcji). Tu pierwsze miejsce zajmowały produkty manufakturowe: artykuły wełniane i metalowe, kapelusze, wyroby płócienne, jedwabne i bawełniane. W drugiej kolejności szły artykuły żywnościowe, głównie zboże, ryby czy chmiel. Ostatnie miejsce zajmował wywóz surowców: ołowiu, cyny i węgla. $Z$ kolei w reeksporcie pierwszoplanową rolę odgrywały artykuły żywnościowe, w większości wcześniej importowane. Następnie produkty manufakturowe: perkale, płótna, jedwabie. Wreszcie w niewielkich ilościach wywożone były surowiec jedwabny i barwniki ${ }^{22}$.

Powyższa struktura obrotu towarowego w całym angielskim handlu zewnętrznym ujawnia jej wręcz modelowe uwarunkowanie merkantylistyczne. W pierwszym rzędzie podporządkowaniu eksportu własnej produkcji manufakturowej i w mniejszym stopniu żywnościowej tej produkcji miał też służyć import surowców. W zakresie wwozu towarów widać też wyraźna jego zależność od reeksportu. $\mathrm{Na}$ ten obrót składały się głównie towary egzotyczne pochodzenia pozaeuropejskiego, choć znaczna część $z$ nich trafiała również na rynek wewnętrzny ${ }^{23}$.

\section{A. Handel z Europa}

Ogólną wielkość angielskich obrotów handlowych z Europa kontynentalna pozwalaja oszacować dane statystyczne ujęte w poniższych tabelach (3 i 4).

Przedstawione dane wskazuja, że ogólny wzrost angielskiego handlu europejskiego w omawianym okresie wynosił $31 \%$ (niewiele ponad 3,5 mln £). Rozwój importu wynosił 26\%, eksportu/reeksportu zaś 33\%. Handel ten cechował się stałym dodatnim bilansem. Natomiast w okresie 1756-1760 odnotował gwałtowny spadek, by równie szybko wzrosnąc na początku lat sześćdziesiątych. Był to efekt przede wszystkim wyhamowania wywozu na rynki europejskie w latach 1756-1760. Co ciekawe, nie dotyczyło to w tym czasie importu, który stopniowo wzrastał, by przyspieszyć w następnej pięciolatce.

${ }^{22}$ Dane za: R. Davis, English Foreign Trade..., s. 295 i 302-303.

${ }^{23}$ Dotyczyło to przede wszystkim cukru, tytoniu i herbaty. Ibidem, s. 300-301. 
Angielski handel z Europa kontynentalna w latach 1741-1765 (w tys. £)

\begin{tabular}{|l|c|c|c|c|c|}
\hline \multicolumn{1}{|c|}{ Lata } & $1741-1745$ & $1746-1750$ & $1751-1755$ & $1756-1760$ & $1761-1765$ \\
\hline Import & 4121 & 4173 & 4340 & 4663 & 5213 \\
\hline $\begin{array}{l}\text { Eksport/ } \\
\text { reeksport }\end{array}$ & 7409 & 8693 & 9760 & 8115 & 9877 \\
\hline Łaccznie & 11530 & 12866 & 14100 & 12778 & 15090 \\
\hline
\end{tabular}

Źródło: E.B. Schumpeter, English Overseas Trade Statistics, 1697-1808, Oxford 1960, s. 17-18.

Tabela 4

Dynamika wzrostu angielskiego handlu z Europa w latach 1741-1765 (w \%)

\begin{tabular}{|l|c|c|c|c|c|}
\hline \multicolumn{1}{|c|}{ Lata } & $1741-1745$ & $1746-1750$ & $1751-1755$ & $1756-1760$ & $1761-1765$ \\
\hline Import & 100 & 101 & 105 & 113 & 126 \\
\hline $\begin{array}{l}\text { Eksport/ } \\
\text { reeksport }\end{array}$ & 100 & 117 & 132 & 109 & 133 \\
\hline Eacznie & 100 & 111 & 122 & 111 & 131 \\
\hline
\end{tabular}

Źródło: obliczenia własne na podstawie tabeli 3.

Analizując rozwój angielskiego handlu z Europą w dobie wspomnianych wojen, warto zwrócić uwagę, jak kształtował się on statystycznie na poszczególnych rynkach. Przedstawiaja to poniższe tabele (od 5 do 12).

Zaprezentowane szacunkowe dane pozwalaja stwierdzić, że w omawianym okresie udział angielskiego handlu na czterech głównych rynkach Europy kontynentalnej wynosił od $81 \%$ do $80 \%{ }^{24}$. Tradycyjnie największy pozostał rynek północno-zachodni, który odnotował jednak spadek o 8\%. Natomiast niewielka tendencję

${ }^{24}$ Pozostałe rynki to Irlandia, wyspy na kanale La Manche i inne pomniejsze posiadłości w strefie M. Północnego. E.B. Schumpeter, op. cit., s. 17-18. 
wzrostowa wykazały trzy pozostałe rynki, które w latach 1761-1765 razem zrównoważyły udział rynku północno-zachodniego.

Tabela 5

Angielski handel na poszczególnych rynkach europejskich w latach 1741-1765 (w tys. £)

\begin{tabular}{|c|c|c|c|c|c|c|}
\hline \multirow{2}{*}{ Lata } & \multicolumn{7}{|c|}{ Rynki europejskie } \\
\cline { 2 - 7 } & Cały & $\begin{array}{c}\text { Północno- } \\
\text {-zachodni }\end{array}$ & Iberyjski & $\begin{array}{c}\text { Północno- } \\
\text {-wschodni }\end{array}$ & $\begin{array}{c}\text { Sródziem- } \\
\text { nomorski }\end{array}$ & Pozostałe \\
\hline $1741-1746$ & 11530 & 5586 & 1695 & 1134 & 934 & 2181 \\
\hline $1761-1765$ & 15090 & 6130 & 2750 & 1802 & 1570 & 2838 \\
\hline
\end{tabular}

Źródło: E.B. Schumpeter, English Overseas Trade Statistics, 1697-1808, Oxford 1960, s. 17-18.

Tabela 6

Angielski handel na poszczególnych rynkach europejskich w latach $1741-1765$ (w \%)

\begin{tabular}{|c|c|c|c|c|c|c|}
\hline \multirow{2}{*}{ Lata } & \multicolumn{6}{|c|}{ Rynki europejskie } \\
\cline { 2 - 7 } & Cały & $\begin{array}{c}\text { Północno- } \\
\text {-zachodni }\end{array}$ & Iberyjski & $\begin{array}{c}\text { Północno- } \\
\text {-wschodni }\end{array}$ & $\begin{array}{c}\text { Śódziem- } \\
\text { nomorski }\end{array}$ & Pozostałe \\
\hline $1741-1746$ & 100 & 48 & 15 & 10 & 8 & 19 \\
\hline $1761-1765$ & 100 & 40 & 18 & 12 & 10 & 20 \\
\hline
\end{tabular}

Źródło: obliczenia własne na podstawie tabeli 6.

W interesujaccym nas okresie udział angielskiego handlu na europejskim rynku północno-zachodnim (Flandria, Holandia, Francja i Niemcy) osiagnał niewielki wzrost, bo zaledwie o 10\% (554 tys. £). Był to efekt zarówno ogólnego spadku importu, jak i okresowych wahań wzrostu eksportu/reeksportu (ogólnie o 14\%) ${ }^{25}$. Angielski

${ }^{25}$ Według ustaleń R. Davisa w latach 1752-1754 reeksport wynosił aż 89\% całego eksportu na ten rynek (a 47\% ogólnego wywozu). Por. i d e m, English Foreign Trade..., s. 302. 
handel na tym rynku odnotował gwałtowny spadek obrotów w latach 1756-1760 (zwłaszcza w obrotach z Flandria i Francja) w stosunku do okresu poprzedniego (aż o $28 \%$ ), co wynikało przede wszystkim z załamania się wwozu (aż o 40\%). Ten czas recesji pokrywał się $z$ kolejna wojna brytyjsko-francuską i działaniami zbrojnymi prowadzonymi także przez pozostałych uczestników wojny siedmioletniej na terenie Rzeszy Niemieckiej. Dopiero w okresie 1761-1765 angielski handel $z$ krajami północno-zachodniej Europy powrócił do stanu sprzed dziesięciolecia. Mimo tych okresowych wahan był to jednak rynek, na którym w angielskim handlu utrzymany został stały dodatni bilans oraz tradycyjnie już największe obroty pod względem wartości (zwłaszcza $z$ Niemcami i Holandia). Jednocześnie był to rynek odnotowujący najmniejszą dynamikę rozwoju ${ }^{26}$.

Z rynku północno-zachodniego brytyjscy kupcy importowali przede wszystkim surowce do tekstylnej produkcji manufakturowej (barwniki, przędzę, len i konopie), ale także żelazo, drewno, skóry. Natomiast w mniejszej ilości gotowe wyroby manufakturowe (tekstylne i metalowe) oraz nieliczne artykuły żywnościowe (m.in. wina i wódki). W omawianym okresie w tych dwóch ostatnich gałęziach importu angielski handel odnotował spadek obrotów. Co się tyczy eksportu, to na rynek północno-zachodni wysyłane były głównie wyroby manufakturowe: wełniane, jedwabne, metalowe, ale też płótna i kapelusze, potem artykuły żywnościowe (zboże, ryby) oraz surowce: ołów, cyna, kute żelazo, mosiądz i węgiel. $Z$ kolei angielski

${ }^{26}$ Jednakże okresowe wahania wzrostu w poszczególnych krajach tego rynku nie pokrywały się z ogólnymi tendencjami jego rozwoju. W Niemczech angielski import odnotował spadek w latach $1746-1755 \mathrm{w}$ stosunku do pięciu lat poprzednich, ale co ciekawe, w okresie 1756-1760 wykazał się wzrostem, by po 1761 r. znów zaznaczyć spadek. Natomiast eksport/reeksport wzrastał w latach 1741-1750, by w następnym dziesięcioleciu odnotować spadek, a w latach 1761-1765 gwałtownie wzrosnać (aż o 67\% w stosunku do pięciu lat poprzednich). Z kolei w Holandii angielski import wykazał się początkowym wzrostem do 1750 r., by spaść w następnym pięcioleciu i znów wzrosnać od 1756 r. Natomiast angielski eksport/reeksport na tym rynku wzrastał do 1755 r., by później znacząco spaść i w okresie 1761-1765 znów rosnać. Odmiennie wyglądały wahania angielskich obrotów handlowych na rynkach flandryjskim (wzrost w okresie pokoju i spadek w czasie wojny) i francuskim. Na tym ostatnim angielski import spadł gwałtownie w latach 1741-1745, ale wzrósł w okresie 1756-1765, za to eksport/reeksport wzrastał do 1755 r. (aż o 87\%), by później odnotować gwałtowny spadek i znów powolny wzrost dopiero na początku lat sześćdziesiątych. Dane za: E.B. Schu m peter, op. cit., s. 17-18. Por. też T.S. Ashton, op. cit., s. 155; J.B. Williams, British Commercial Policy and Trade Expansion 1750-1850, Oxford 1972, s. 196. 
reeksport na ten rynek zawierał przede wszystkim artykuły kolonialne (tytoń, ryż, pieprz, kawę), wśród których uderza brak cukru $^{27}$, za to pojawiaja się jedwabie, perkale, płótna oraz surowce do wyrobu tych tkanin (w tym barwniki) ${ }^{28}$.

Tabela 7

Angielski handel z północno-zachodnią Europa w latach 1741-1765 (w tys. £)

\begin{tabular}{|l|c|c|c|c|c|}
\hline \multicolumn{7}{|c|}{ Rynek północno-zachodni } \\
\hline \multicolumn{1}{|c|}{ Lata } & $1741-1745$ & $1746-1750$ & $1751-1755$ & $1756-1760$ & $1761-1765$ \\
\hline Import & 1311 & 1251 & 1089 & 1209 & 1250 \\
\hline $\begin{array}{l}\text { Eksport/ } \\
\text { reeksport }\end{array}$ & 4275 & 4593 & 5045 & 3354 & 4880 \\
\hline Eacznie & 5586 & 5844 & 6134 & 4563 & 6130 \\
\hline
\end{tabular}

Źródło: E.B. Schumpeter, English Overseas Trade Statistics, 1697-1808, Oxford 1960, s. 17-18.

${ }^{27}$ Por. F.W. Pitman, The Development of the British West Indies, 1700-1763, New Haven 1917, s. 158, 160, 162 (dane ujęte w tabelach przez tego autora wskazuja, poza ogólna tendencją spadkowa udziału eksportowanego przez Anglię cukru na europejskim rynku, także jej skokowy charakter). Reeksport tego towaru był już od lat dwudziestych XVIII w. stopniowo wypierany przez reeksport cukru francuskiego. Na wyspie St. Dominique ok. 1715 r. produkowano 6-7 tys. ton cukru rocznie (138 cukrowni), ale już w 1743 r. 43 tys. ton (600 cukrowni), co przewyższało produkcję cukru wszystkich brytyjskich wysp na Antylach. Na Martynice w 1715 r. (186 cukrowni) produkowano 5 tys. ton rocznie, a w latach pięćdziesiątych ok. 20 tys. ton rocznie (546 cukrowni). Gwadelupa w tym samym okresie przeszła od 2 tys. do ok. 8 tys. ton rocznie. Biorac pod uwage, że Francuzi konsumowali znacznie mniej cukru niż Brytyjczycy, to nadwyżki importu przeznaczali na tańszy reeksport do Europy. Przy jednocześnie rosnacych cenach cukru handel nim stawał się dosłownie wyjątkowo lukratywnym przedsięwzięciem kupieckim. Mémoires du comte de Maurepas, Ministre de la Marine, etc., vol. III, Paris 1792, s. 111-112. Por. też P. Butel, Historie des Antillles françaises XVIIe-XXe siècles, Paris 2007, s. 119-134; idem, The Atlantic, London 1999, s. 152-153; M. Devèzi e, Antillles, Guyanes, la mer des Caraïbes de 1492 à 1789, Paris 1985, s. 255-260.

${ }^{28}$ R. Cambe11, The London Tradesman (London 1747), [w:] English Historical Document [dalej: EHD], vol. IX, eds D.B. Horn, M. Randsome, London 1957, s. 497; R. Davis, English Foreign Trade...., s. 300-301; J.B. William s, op. cit., s. 196. 
Dynamika wzrostu angielskiego handlu z północno-zachodnia Europa (w \%)

\begin{tabular}{|l|c|c|c|c|c|}
\hline \multicolumn{7}{|c|}{ Rynek północno-zachodni } \\
\hline \multicolumn{1}{|c|}{ Lata } & $1741-1745$ & $1746-1750$ & $1751-1755$ & $1756-1760$ & $1761-1765$ \\
\hline Import & 100 & 95 & 83 & 92 & 95 \\
\hline $\begin{array}{l}\text { Eksport/ } \\
\text { reeksport }\end{array}$ & 100 & 107 & 118 & 78 & 114 \\
\hline Lacznie & 100 & 105 & 110 & 82 & 110 \\
\hline
\end{tabular}

Źródło: obliczenia własne na podstawie tabeli 5.

Centrum angielskiego handlu na rynku północno-zachodnim znajdowało się w Hamburgu, ale docierał on też do innych portów niemieckich: Bremy, Lubeki czy Szczecina. Stąd angielskie towary trafiały, zazwyczaj wykorzystując żegluge rzeczna, na wszystkie największe w Rzeszy targi, a nawet obszary nadgraniczne (w Niderlandach i na wschodzie) ${ }^{29}$. Kolejny ważny rynek w angielskim handlu europejskim stanowiły kraje iberyjskie.

Tabela 9

Angielski handel $z$ krajami iberyjskimi w latach 1741-1765 (w tys. £)

\begin{tabular}{|l|c|c|c|c|c|}
\hline \multicolumn{7}{|c|}{ Rynek iberyjski } \\
\hline \multicolumn{1}{|c|}{ Lata } & $1741-1745$ & $1746-1750$ & $1751-1755$ & $1756-1760$ & $1761-1765$ \\
\hline Import & 493 & 575 & 677 & 670 & 763 \\
\hline $\begin{array}{l}\text { Eksport/ } \\
\text { reeksport }\end{array}$ & 1202 & 1816 & 2136 & 2575 & 1987 \\
\hline Lacznie & 1695 & 2391 & 2813 & 3245 & 2750 \\
\hline
\end{tabular}

Źródło: E.B. Schumpeter, English Overseas Trade Statistics, 1697-1808, Oxford 1960, s. 17-18.

${ }^{29}$ T.S. Ashton, op. cit., s. 155; J.B. Williams, op. cit., s. 196. 
Tabela 10

Dynamika wzrostu angielskiego handlu z krajami iberyjskimi (w \%)

\begin{tabular}{|l|c|c|c|c|c|}
\hline \multicolumn{7}{|c|}{ Rynek iberyjski } \\
\hline \multicolumn{1}{|c|}{ Lata } & $1741-1745$ & $1746-1750$ & $1751-1755$ & $1756-1760$ & $1761-1765$ \\
\hline Import & 100 & 117 & 137 & 136 & 155 \\
\hline $\begin{array}{l}\text { Eksport/ } \\
\text { reeksport }\end{array}$ & 100 & 151 & 178 & 214 & 165 \\
\hline Eacznie & 100 & 141 & 166 & 191 & 162 \\
\hline
\end{tabular}

Źródło: obliczenia własne na podstawie tabeli 9.

Z powyższych danych statystycznych wynika, że w badanym okresie w krajach iberyjskich (Portugalia, Hiszpania) angielski handel wzrósł o 62\% (do lat 1756-1760 niemal się podwoił). Wiązało się to $z$ ogólnym wysokim wzrostem importu o $55 \%$ i jeszcze wyższym eksportu/reeksportu, który wynosił aż 65\%. Nie ulega jednak wątpliwości, że w odniesieniu do lat wcześniejszych angielski handel w krajach iberyjskich szczytowy okres miał już za sobą ${ }^{30}$. Jednakże mimo okresowych wahań zachował stały dodatni bilans handlowy ${ }^{31}$. Wielka Brytania cieszyła się uprzywilejowana pozycja na rynku iberyjskim, przede wszystkim portugalskim, co wynikało z wcześniejszych zobowiązań traktatowych ${ }^{32}$. Aczkolwiek wprowa-

30 Dane za: E.B. Schumpeter, op. cit., s. 17-18. Por. też A. Attman, American Bullion in the European World Trade 1600-1800, Goteborg 1986, s. 62-68; História de Portugal, vol. IV (O Antigo Regime [1620-1807), ed. D.A.M. Hespanha, Janeiro 1998, s. 94-95 i 98-99.

${ }^{31} \mathrm{~W}$ zakresie importu angielski handel w latach 1741-1745 odnotował wzrost, a potem spadek aż do 1760 r. Natomiast Portugalia była dla Anglii trzecim rynkiem eksportowym/reeksportowym, ale szczyt tych obrotów przypadł na lata 1736-1740, potem spadek aż do 1756 r. i znów w okresie 1761-1765. Z kolei Hiszpania odnotowała gwałtowny spadek ogólnych obrotów handlowych $z$ Anglia w latach wojny 1741-1745, by w następnych okresach wykazać wzrost eksportu/ reeksportu oraz importu. Por. A. Attman, op. cit., s. 62-64; E.B. Schum peter, op. cit., s. 17-18; E.B. William s, op. cit., s. 149-150.

${ }^{32}$ Układ z 1703 r. (poprzedzony umowa z 1654 r.), znany jako traktat lorda Johna Methuena, obniżał cła na portugalskie wina na angielskim rynku, w zamian za co Lizbona zgodziła się otworzyć swój rynek na angielskie towary wełniane. Por. T.S. A s h to n, op. cit., s. 155; J. Bla ck, A System of Ambition..., s. 94; História de Portugal..., s. 94; J.B. Williams, op. cit., s. 149-150. Natomiast przyznane 
dzana w państwach iberyjskich od początku lat sześćdziesiątych polityka protekcjonistyczna oraz kolejna wojna brytyjsko-hiszpańska (1762-1763) dość szybko doprowadziły do znacznego ograniczenia angielskiej obecności na tym rynku (o 29\%) ${ }^{33}$.

$\mathrm{W}$ angielskim imporcie rynek iberyjski był przede wszystkim dostawca amerykańskich kruszców niezbędnych do handlu $z$ Indiami Wschodnimi ${ }^{34}$. Poza tym płynęły stamtąd do brytyjskich portów głównie artykuły żywnościowe (wina, owoce, oliwa, brazylijski cukier) oraz surowce (wełna). Natomiast brytyjscy kupcy eksportowali produkty manufakturowe: tekstylne i metalowe, zboże, ołów, cynę, a reeksportowali głównie artykuły kolonialne: żywnościowe (tytoń, kawę, pieprz, ryż), manufakturowe (perkale, jedwabie) i surowce (barwniki). Znaczna część angielskiego wwozu na rynek iberyjski stawała się potem portugalskim lub hiszpańskim reeksportem do iberoamerykańskich kolonii ${ }^{35}$.

Brytyjczykom w 1713 r. na mocy traktatów z Hiszpanią na 30 lat asiento (na ograniczony handel niewolnikami) $z$ prawem wysyłania jednego statku rocznie $z$ towarami do wyznaczonych portów na obu oceanicznych brzegach Hispanoameryki, przekazane Kompanii Mórz Południowych (South Sea Company), zostało zawieszone na czas wojny (1739-1748). W 1750 r. Brytyjczycy zawarli kolejny dla nich korzystny układ z Madrytem przywracajacy im część dawnych przywilejów. $E H D$, ed. A. Browning, vol. VIII, London 1953, s. 883-885. Por. J. Black, British Diplomats and Diplomacy, 1688-1800, Exeter 2001, s. 151; D. M cKey, H.M. Scott, op. cit., s. 65-66 i 177; J.H. Parry, Morskie imperium Hiszpanii, Gdańsk 1983, s. 278-280; L. Vigno1, L'Asiento français (1701-1713) et anglais (1713-1750) et le commerce franco-espagnol vers 1700 à 1730, „Revue d'Histoire Economique et Sociale” 1929, vol. XVII, No. 3, s. 411-412. J.B. William s, op. cit., s. 149-150 i 156.

${ }^{33}$ Wprowadzane przez ministra markiza Pombal od początku lat sześćdziesiatych XVIII w. cła prohibicyjne w Portugalii ograniczyły uprzywilejowana pozycję brytyjskich towarów, zwłaszcza tekstyliów. Podobnie hiszpańska polityka protekcjonistyczna wprowadzona w tym samym czasie, a wkrótce nowa wojna (1762-1763) zakwestionowały brytyjskie panowanie na tym rynku. J. Bla ck, A System of Ambition..., s. 94-96; i d e m, British Diplomats..., s. 150; A. Ch ris telow, Great Britain and the Trades from Cadiz and Lisbon to Spanish America and Brazil, 1759-1783, „Hispanic American Historical Review” 1947, vol. XXVII, No. 1, s. 15-17; S. Conw a y, op. cit., s. 102-103; História de Portugal..., s. 98-99; J.B. Willia m s, op. cit., s. $148-149$ i 156.

${ }^{34} \mathrm{~W}$ ten sposób pokrywane były angielskie nadwyżki w handlu $\mathrm{z}$ krajami iberyjskimi (złotem i srebrem $z$ amerykańskich kopalń; $z$ Brazylii płynęło złoto do Anglii via Lizbona rocznie na sumę ok. 1,2-1,6 mln £). Spadek tych nadwyżek po 1760 r. spowodował też zmniejszenie napływu kruszców do Wielkiej Brytanii. Por. A. Attman, op. cit., s. 64-67.

${ }^{35}$ R. Cambe11, op. cit., s. 497; A. A11tman, op. cit., s. 63; R. Davis, English Foreign Trade..., s. 300-301; id e m, A Commercial Revolution..., s. 20; História de Portugal..., s. 98-99; E.B. William s, op. cit., s. 156. 
Tymczasem obok zachodniej i południowej Europy coraz większe znaczenie dla angielskiego handlu zaczął odgrywać rynek północno-wschodni.

Tabela 11

Angielski handel z krajami północno-wschodnimi w latach 1741-1765 (w tys. £)

\begin{tabular}{|l|c|c|c|c|c|}
\hline \multicolumn{7}{|c|}{ Rynek północno-wschodni } \\
\hline \multicolumn{1}{|c|}{ Lata } & $1741-1745$ & $1746-1750$ & $1751-1755$ & $1756-1760$ & $1761-1765$ \\
\hline Import & 795 & 939 & 1050 & 1128 & 1308 \\
\hline $\begin{array}{l}\text { Eksport/ } \\
\text { reeksport }\end{array}$ & 339 & 353 & 376 & 329 & 494 \\
\hline Eacznie & 1134 & 1292 & 1426 & 1457 & 1802 \\
\hline
\end{tabular}

Źródło: E.B. Schumpeter, English Overseas Trade Statistics, 1697-1808, Oxford 1960, s. 17-18.

Tabela 12

Dynamika wzrostu angielskiego handlu z krajami północno-wschodnimi (w \%)

\begin{tabular}{|l|c|c|c|c|c|}
\hline \multicolumn{7}{|c|}{ Rynek północno-wschodni } \\
\hline \multicolumn{1}{|c|}{ Lata } & $1741-1745$ & $1746-1750$ & $1751-1755$ & $1756-1760$ & $1761-1765$ \\
\hline Import & 100 & 118 & 132 & 142 & 164 \\
\hline $\begin{array}{l}\text { Eksport/ } \\
\text { reeksport }\end{array}$ & 100 & 104 & 111 & 97 & 146 \\
\hline Eacznie & 100 & 114 & 126 & 128 & 159 \\
\hline
\end{tabular}

Źródło: obliczenia własne na podstawie tabeli 11.

W analizowanym okresie udział angielskiego handlu na rynku północno-wschodnim (Dania, Norwegia, Szwecja, Prusy, Polska, Rosja) osiągnął ogólny wzrost o 59\%, w tym importu aż o 64\%, a eksportu/reeksportu o 46\%. Dla tego ostatniego sektora wymiany 
istotny spadek wywozu nastapił w latach 1756-1760, w czym niewątpliwie należy widzieć efekt działań wojennych w strefie nadbałtyckiej (Prusy Wschodnie, Pomorze Zachodnie, Brandenburgia). Poza tym stała cechą angielskiego handlu $z$ krajami tej części Europy była znaczna przewaga importu nad eksportem, co czyniło ten rynek wyjątkowo deficytowym. Wielka Brytania importowała $z$ krajów nadbałtyckich i wschodnich przede wszystkim surowce niezbędne do rozwoju jej floty. Należały do nich żelazo, drewno, skóry, ale też len i konopie. Ponadto na liście artykułów importowanych, ale w mniejszej ilości, znalazły się perkal, przędza, smoła, $z$ ioła $^{36}$. Ze względu na taki profil importu wyjatkowe znaczenie dla Wielkiej Brytanii na rynku północno-wschodnim zaczęła zdobywać, co najmniej od lat pięćdziesiątych, Rosja. Zdystansowała w zakresie angielskiego importu nie tylko inne państwa strefy nadbałtyckiej, lecz w latach 1761-1765 także pozostałe kraje europejskie. Ogólny wzrost angielskiego wywozu $z$ Rosji w latach 1741-1765 wynosił aż 179\%. Natomiast w obszarze eksportu/reeksportu państwo carów było znacznie mniejszym rynkiem, dodatkowo podlegającym okresowym wahaniom $^{37}$. Większymi rynkami wwozu dla brytyjskich kupców okazały się państwa skandynawskie, ale też Prusy i Polska. W zakresie eksportu dostarczali oni do krajów strefy nadbałtyckiej wyroby manufakturowe: tekstylne (głównie wełniane, ale też jedwabne, trochę płócien) i metalowe, jak również zboże, ryby, a $z$ surowców ołów i cynę. Natomiast angielski reeksport na ten rynek oferował w pierwszym rzędzie artykuły żywnościowe, manufakturowe i surowcowe, głównie kolonialne (tytoń, pieprz, kawa, ryż oraz perkale, jedwabie, płótna i barwniki) ${ }^{38}$.

36 R. Cambe11, op. cit., s. 497; R. D avis, English Foreign Trade..., s. 300-301.

37 Angielski eksport/reeksport na rynek rosyjski w latach 1741-1755 odnotował wzrost, a w następnym dziesięcioleciu spadek. E.B. Schumpeter, op. cit., s. 17-18. Wielka Brytania zawarła $z$ Rosja traktat handlowy w 1734 r. dajacy uprzywilejowana pozycję jej towarom na tym rynku. Po jego wygaśnięciu od 1759 do 1766 r. trwały negocjacje nad jego odnowieniem, które choć zakończone pomyślnie, nie zostały uznane przez rząd w Londynie, mimo że jego warunki satysfakcjonowały brytyjskich kupców. J.B. William s, op. cit., s. 169-170.

${ }^{38}$ Według wyliczeń R. D avis a w latach 1752-1754 reeksport na rynek północno-wschodni stanowił 33\% angielskiego eksportu, a 25\% łącznego wywozu. Id e m, English Foreign Trade..., s. 300-301; id e m, A Commercial Revolution..., s. 21. Co ciekawe, angielski reeksport kawy i herbaty nie docierał bezpośrednio na rynek Rzeczpospolitej (za pośrednictwem Gdańska). S. Gie r s zew s ki, Statystyka żeglugi Gdańska w latach 1670-1815, Warszawa 1963, s. 72-137. Nie można jednak wykluczyć, że te egzotyczne napoje stanowiły jakąś część reeksportu duńskiego i szwedzkiego. 
Wreszcie też istotnym dla angielskiego handlu był rynek śródziemnomorski (w tym lewantyński) mający długa tradycję kontaktów z Wyspami Brytyjskimi.

Angielski handel $z$ krajami śródziemnomorskimi (i z Lewantem) w latach 1741-1765 (w tys. £)

\begin{tabular}{|l|c|c|c|c|c|}
\hline \multicolumn{7}{|c|}{ Rynek śródziemnomorski (w tym lewantyński) } \\
\hline \multicolumn{1}{|c|}{ Lata } & $1741-1745$ & $1746-1750$ & $1751-1755$ & $1756-1760$ & $1761-1765$ \\
\hline Import & 735 & 692 & 793 & 690 & 921 \\
\hline $\begin{array}{l}\text { Eksport/ } \\
\text { reeksport }\end{array}$ & 199 & 320 & 381 & 346 & 649 \\
\hline Eacznie & 934 & 1012 & 1174 & 1036 & 1570 \\
\hline
\end{tabular}

Źródło: E.B. Schumpeter, English Overseas Trade Statistics, 1697-1808, Oxford 1960, s. 17-18.

Dynamika wzrostu angielskiego handlu z krajami śródziemnomorskimi, $\mathrm{w}$ tym $\mathrm{z}$ Lewantem (w \%)

\begin{tabular}{|l|c|c|c|c|c|}
\hline \multicolumn{7}{|c|}{ Rynek śródziemnomorski (w tym lewantyński) } \\
\hline \multicolumn{1}{|c|}{ Lata } & $1741-1745$ & $1746-1750$ & $1751-1755$ & $1756-1760$ & $1761-1765$ \\
\hline Import & 100 & 94 & 108 & 94 & 125 \\
\hline $\begin{array}{l}\text { Eksport/ } \\
\text { reeksport }\end{array}$ & 100 & 161 & 191 & 174 & 326 \\
\hline Lacznie & 100 & 108 & 126 & 111 & 168 \\
\hline
\end{tabular}

Źródło: obliczenia własne na podstawie tabeli 13. 
Powyższe dane wskazuja, że w latach 1741-1765 angielski handel na rynku śródziemnomorskim (kraje Płw. Apenińskiego $z$ Wenecją) i lewantyńskim (Turcja) wykazał ogólny wzrost o 68\% (do 1755 r. o $26 \%$ ), w tym importu o $25 \%$ (do 1755 r. $8 \%$ ), a eksportu/reeksportu aż o $226 \%$ (do 1755 r. tylko o 91\%) ${ }^{39}$. Ten zaskakująco wysoki wzrost wywozu był efektem ogólnego przyspieszenia angielskich obrotów handlowych na tym rynku (przede wszystkim włoskim) po spadku ich wartości (importu o 14\%, a eksportu/reeksportu o 17\%) w latach 1756-1760 (zwłaszcza w wymianie $z$ Turcja) ${ }^{40}$. Poza tym w obrotach $z$ krajami włoskimi i Turcja angielski handel był stale deficytowy. W omawianym okresie odnotował bowiem znaczna przewagę importu nad eksportem/reeksportem. Trudno również nie zauważyć, że rynek śródziemnomorski i lewantyński miał najniższą wartość obrotów ze wszystkich angielskich rynków w Europie kontynentalnej.

Angielski import $z$ krajów włoskich i Lewantu dostarczał przede wszystkim artykułów żywnościowych (wina, owoce, zboże, zioła lecznicze) i surowców (olej, barwniki, przędza, bawełna) oraz tekstylnych produktów manufakturowych (jedwab i inne tkaniny). Natomiast angielski wywóz na rynek śródziemnomorski (i lewantyński) zawierał w pierwszej kolejności tekstylne i metalowe produkty manufakturowe oraz surowce (ołów, cyna), a w ramach reeksportu brytyjscy kupcy przywozili nieliczne artykuły kolonialne (tytoń, kawa, barwniki) ${ }^{41}$.

\section{B. Handel pozaeuropejski (i kolonialny)}

Dostrzegalny wzrost reeksportu, przede wszystkim zamorskiego, $\mathrm{w}$ angielskim eksporcie na omówionych rynkach europejskich, w tym największym północno-zachodnim i rozrastającym się północno-wschodnim, wskazywał na rosnace znaczenie handlowej

39 Jednak wartość obrotów handlowych $z$ krajami włoskimi ( $\mathrm{z}$ uwzględnieniem okresowych wahań na rynku weneckim) była znacznie wyższa niż z Turcją, której udział w rynku śródziemnomorskim w latach 1741-1765 spadł z 27\% do zaledwie $13 \%$, choć w bezpośrednich relacjach $z$ Wielka Brytania handel lewantyński w omawianym okresie wzrósł o $22 \%$ (angielski import cały czas spadał, natomiast eksport/reeksport rósł do 1750 r., potem spadał i znów odnotował progres od początku lat sześćdziesiątych), a angielski handel na rynku włoskim się podwoił. Obliczenia na podstawie danych za: E.B. Schumpeter, op. cit., s. 17-18.

${ }^{40}$ D.C. Coleman, op. cit., s. 149; E.B. Schumpeter, op. cit., s. 17-18.

${ }^{41}$ R. Ca m bel1, op. cit., s. 497-498; R. D a vi s, English Foreign Trade..., s. 300-303. 
wymiany pozaeuropejskiej. Wielkość tej wymiany w analizowanym okresie pozwalają ocenić przedstawione poniżej dane statystyczne.

Tabela 15

Angielski handel pozaeuropejski (i kolonialny) w latach 1741-1765 (w tys. £)

\begin{tabular}{|l|c|c|c|c|c|}
\hline \multicolumn{1}{|c|}{ Lata } & $1741-1745$ & $1746-1750$ & $1751-1755$ & $1756-1760$ & $1761-1765$ \\
\hline Import & 3047 & 3051 & 3793 & 3662 & 4812 \\
\hline $\begin{array}{l}\text { Eksport/ } \\
\text { reeksport }\end{array}$ & 2084 & 2459 & 3025 & 4038 & 4559 \\
\hline Eacznie & 5131 & 5510 & 6818 & 7700 & 9371 \\
\hline
\end{tabular}

Źródło: E.B. Schumpeter, English Overseas Trade Statistics, 1697-1808, Oxford 1960, s. 17-18.

Tabela 16

Dynamika wzrostu angielskiego handlu pozaeuropejskiego w latach 1741-1765 (w \%)

\begin{tabular}{|l|c|c|c|c|c|}
\hline \multicolumn{1}{|c|}{ Lata } & $1741-1745$ & $1746-1750$ & $1751-1755$ & $1756-1760$ & $1761-1765$ \\
\hline Import & 100 & 100 & 124 & 120 & 160 \\
\hline $\begin{array}{l}\text { Eksport/ } \\
\text { reeksport }\end{array}$ & 100 & 118 & 145 & 194 & 219 \\
\hline Łacznie & 100 & 107 & 133 & 150 & 182 \\
\hline
\end{tabular}

Źródło: obliczenia własne na podstawie tabeli 15.

Z zamieszczonych danych wynika, że w latach 1741-1765 ogólny wzrost angielskiego handlu pozaeuropejskiego (w tym kolonialnego) wzrósł o $82 \%$, w tym importu o $60 \%$, a eksportu/reeksportu aż o $119 \%$. O ile w latach 1756-1760 wystąpił spadek wzrostu importu (o 4\%), to wywóz w tym czasie znacznie wzrósł (o 49\% w stosun$\mathrm{ku}$ do lat 1751-1755). Poza tym w omawianym okresie angielski eksport/reeksport pozaeuropejski zachował stały wzrost. Dzięki tak 
znacznej progresji dalekosiężnego wywozu zamorskiego angielski handel pozaeuropejski stawał się w coraz większym stopniu proeksportowy. Nie zmieniło to jednak faktu, że ze względu na wielkość importu wymiana ta zachowała charakter deficytowy ( $z$ wyjątkiem lat 1756-1760), ale w ostatnim analizowanym pięcioleciu zbliżyła się do zrównoważonego bilansu. Ponadto dynamika rozwoju tego handlu była ponad dwuipółkrotnie wyższa (164\%) niż handlu $z$ Europa. Wielkość obrotów pozaeuropejskiej wymiany w stosunku do całości handlu wzrosła z 31\% do 38\% (ponad 1/3).

Angielski handel pozaeuropejski (i kolonialny), poczawszy od drugiej połowy XVII w., podzielony był na dwa podstawowe rynki: atlantycki i azjatycki. W badanych latach 1741-1765 ten pierwszy składał się $z$ brytyjskich faktorii położonych na środkowym wybrzeżu Afryki Zachodniej, z posiadłości kolonialnych usytuowanych na „cukrowych wyspach” Morza Karaibskiego (część Małych i Wielkich Antyli, zwłaszcza Jamajka, Barbados, Bermudy) oraz $z$ coraz bardziej zagęszczonego osadnictwa usytuowanego wzdłuż wschodniego wybrzeża Ameryki Północnej (w 13 prowincjach od Maine na północy po Georgię na południu). Po 1713 r. na tym kontynencie dochodziła część kanadyjskiej Akadii (Nowej Szkocji) oraz Nowa Fundlandia, ale były to tereny zbyt słabo zaludnione, aby mieć jakieś większe znaczenie handlowe. W latach 1759-1760 Brytyjczycy zajęli francuska Kanadę. Osady Quebec i Montreal szybko stały się pożądanymi nowymi rynkami dla angielskiego handlu zamorskiego ${ }^{42}$. Poza tym handel ten obejmowal przytoczone „nieformalne imperium" w Ameryce Południowej, choć w odniesieniu do posiadłości hispanoamerykańskich podlegające konsekwencjom wspomnianych konfliktów zbrojnych. Ostatni z nich, rozpoczęty w 1762 r., pozwolił Brytyjczykom, choć na krótko, zajać Kubę ( $z$ ważnym portem w Hawanie). Weszli też w posiadanie kilku francuskich "cukrowych wysp” w Archipelagu Małych Antyli (w szczególności Martyniki i Gwadelupy), które do 1763 r. zostały włączone $\mathrm{w}$ angielski handel atlantycki ${ }^{43}$.

${ }^{42}$ W.S. Dunn jr., Opening New Markets: The British Army and the Old North-west, Westport 2002, s. 17-18 i 75-76; J.B. Willia m s, op. cit., s. 440.

${ }^{43}$ Hawana i Gwadelupa stały się kwitnacymi centrami angielskiego importu. Dochodziła do tego prowadzona przez Amerykanów kontrabanda $z$ francuskimi Indiami Zachodnimi. W.S. Dunn jr., op. cit., s. 76; J.R. McNei11, Atlantic Empires of France and Spain: Louisbourg and Havana, 1700-1763, Chapel Hill 1985, s. 191-202; R.B. Sh erid a n, Sugar and Slavery: An Economic History of the British West Indies, 1623-1775, Kingston 1974, s. 316-319 i 450-452. 
Rozłożony na tak wielkiej przestrzeni obszar wymiany handlowej, obejmującej aż cztery kontynenty (Afryka, obie Ameryki i Europa) i przebiegającej na wielu szlakach oceanicznych, tworzył podstawę wspomnianej „atlantyckiej gospodarki” Wielkiej Brytanii. Z jednej strony opierała się ona na sieci wzajemnych powiązań handlowych między brytyjskimi koloniami od Nowej Szkocji po Indie Zachodnie (obrót głównie surowców, bydła, koni oraz żywności i napojów, w tym cukru, kakao, melasy i rumu, rzadziej gotowych wyrobów przemysłowych). $Z$ drugiej zaś strony - na bezpośredniej wymianie między tymi posiadłościami a metropolia, która importowała surowce (bawełna, żelazo), barwniki, drewno, żywność (przede wszystkim artykuły tropikalne: kawa, kakao, ryż) i używki (tytoń). Sama natomiast była eksporterem/reeksporterem przede wszystkim produktów manufakturowych tekstylnych (wełnianych, lnianych, jedwabnych, bawełnianych) i metalowych ( $z$ miedzi, mosiądzu i żelaza), ale też artykułów kolonialnych (herbata, bawełna), surowców (węgiel, niewielkie ilości cyny i ołowiu), żywności i innych towarów, jak kapelusze, galanteria, wyroby jubilerskie, leki, papier, książki, karty, zegary, wagi, miechy, buty, mydło, siekiery, meble, sztućce, rondle czy wyroby ze szkła, a także muszkiety, pistolety, proch, a nawet armaty (uzbrojenie fortów) ${ }^{44}$.

Natomiast we wschodniej części „atlantyckiej gospodarki” stopniowo rosło znaczenie rynku zachodnioafrykańskiego. W pierwszym rzędzie stawał się on coraz bardziej chłonny dla angielskiego eksportu/reeksportu. Odbiorcami na tym rynku byli nie tylko przebywający w tej części Brytyjczycy (i przedstawiciele innych kolonii europejskich), ale głównie ludność autochtoniczna ${ }^{45}$. Na rynek ten trafiały brytyjskie lżejsze wyroby tekstylne (bawełniane lub bawełniano-lniane), szklane, metalowe (w tym mosiężne patelnie) i miedziane, zwoje drutu, konie, łój, fajki, alkohol, broń biała i palna oraz proch strzelniczy. Reeksport zaś dostarczał przede wszystkim

${ }^{44}$ Ch.M. Andrew s, Colonial Commerce, „American Historical Review” 1914, vol. XX, No. 1, s. 53-60; R. Davis, English Foreign Trade..., s. 302-304; ide m, A Commercial Revolution..., s. 20-21; W.S. D unn jr., op. cit., s. 17; M. En ge1, The Economic Development of the Thirteen Continental Colonies, 1720 to 1775, „William and Mary Quarterly” 1975, vol. XXXII, No. 2, s. 205-212; R. Po pe, Atlas of British Social and Economic History Since c. 1700, London 1990, s. 116-118; M.J. Rozb icki, Gospodarka brytyjskiej Ameryki Północnej w XVIII w., [w:] Historia Stanów Zjednoczonych Ameryki..., t. I, s. 209-210; R.B. Sheridan, op. cit., s. 313-315; J.B. Williams, op. cit., s. 9.

${ }^{45}$ R. Davis, English Foreign Trade..., s. 291. 
rum i tytoń $z$ brytyjskich posiadłości po drugiej stronie Atlantyku oraz wyroby tekstylne, paciorki i muszelki znad Oceanu Indyjskiego i Indii Wschodnich. Za przywożone do Afryki Zachodniej towary (był to podstawowy środek płatniczy, choć używano także srebrnych monet) brytyjscy kupcy nabywali kość słoniowa, złoto, surowce (żelazo i miedź). Te towary wchodziły w skład angielskiego importu $z$ Afryki ${ }^{46}$. Jednakże najbardziej dochodowy był zakup niewolników. Ten obrót „czarnym towarem”, zarazem najważniejszy „afrykański eksport” Anglii do obu Ameryk, łączył w ten sposób zachodnią część tego kontynentu $z$ atlantyckimi sieciami wymiany w ramach tzw. handlu trójkątnego (triangle trade). Jednocześnie stanowił o opłacalności całego angielskiego handlu z Afryką Zachodnia ${ }^{47}$.

W XVIII w., przede wszystkim w portugalskiej Brazylii, ale także na „cukrowych wyspach" na Karaibach, w tym brytyjskich, gwałtownie rósł popyt na pracę Afrykanów. Ich wysiłek obniżał bowiem koszty produkcji gospodarki plantatorskiej i był jednym z czynników jej dochodowości w eksporcie do metropolii i reeksporcie na rynki Starego Kontynentu. Nic więc dziwnego, że w latach 1741-1765 brytyjscy handlarze niewolników przewieźli do tylko brytyjskich posiadłości na Antylach i w Ameryce Północnej prawie 400 tys. osób. Najwięcej $z$ nich trafiło na Jamajkę, bo aż 120 tys. ${ }^{48}$ Wiodaca rolę w tym procederze zaczęli odgrywać w tym czasie inwestorzy, kupcy i żeglarze $z$ Liverpoolu, wysyłając najwięcej statków niewolniczych $z$ Afryki Zachodniej do obu Ameryk. Zdystansowali zatem dawne ośrodki tego handlu w Bristolu i w Londynie ${ }^{49}$. Poza

${ }^{46}$ R. Cambe11, op. cit., s. 498. Por. też R. Davis, English Foreign Trade..., s. 291; J. Iliffe, op. cit., s. 164; K. Morgan, Slavery and the British Empire: from Africa to America, Oxford 2007, s. 67-71; H. Zins, op. cit., s. 77 i 79.

${ }^{47}$ R.B. Sheridan, The Commercial and Financial Organization of the British Slave Trade, 1750-1807, EcHR 1958, vol. XL, No. 2, s. 249-250.

48 Natomiast w omawianym okresie trafiło na Barbados 57 tys., na inne „cukrowe wyspy” 22 tys., a do brytyjskiej Ameryki Północnej ok. 100 tys. Afrykanów. Dane za: Ph. Curtis, The Atlantic Slave Trade, A Census, Madison 1969, s. 119 i 216. Z kolei D. E1tis podaje zbliżone dane: w latach 1751-1775 łącznie trafiło do brytyjskich kolonii za Atlantykiem 577,7 tys. Afrykanów, z czego tylko na Jamajke 312 tys. Id e m, The Volume and Structure of the Transatlantic Slave trade: A Reassessment, „William and Mary Quarterly” 2001, vol. LVIII, No. 1, s. 45. Por. też R.B. Sh erid a n, The Commerial and Financial Organization..., s. 259.

${ }^{49}$ K. Morgan, op. cit., s. 63-65; idem, Liverpool's Dominance in the British Slave Trade, 1740-1807, [w:] Liverpool and Transatlantic Slavery, eds D. Richardson, S. Schwarz, Liverpool 2007, s. 21-34; J.A. Rawley, London, Metropolis of Slave Trade, Columbia 2003, s. 39. 
tym brytyjscy handlarze dostarczali też Afrykanów, legalnie bądź częściej w postaci kontrabandy, do kolonialnych posiadłości innych państw europejskich, jednocześnie utrzymując brytyjskie „nieformalne imperium" także w czasie wspomnianych wojen ${ }^{50}$. Różnymi zatem drogami niewolniczy handel ugruntowywał pozycje Afryki Zachodniej w „atlantyckiej gospodarce” Wielkiej Brytanii. O jego znaczacej roli w 1750 r. Horace Walpole napisał, że stanowił on „niewyczerpane źródło bogactwa i siły morskiej” tego państwa ${ }^{51}$.

Powyższy system atlantyckiej wymiany, towarów, kruszców, pieniędzy i ludzi nadal funkcjonował w ramach legislacyjnych ograniczeń wyznaczonych merkantylnymi potrzebami metropolii ${ }^{52}$. Natomiast ujawniał się, podobnie jak wcześniej w handlu $z$ Europa, postępujący spadek znaczenia obdarzonych królewskim monopolem kompanii handlowych, powstałych zazwyczaj w poprzednim stuleciu. Ich miejsce zajmowali indywidualni kupcy, przedsiębiorcy oraz inni inwestorzy (tworzacy zazwyczaj małe spółki bądź organizacje kupieckie). W ten sposób poszerzała się konkurencyjna wobec królewskich monopoli strefa wolnego handlu w „atlantyckiej gospodarce”. W największym stopniu, zarazem paradoksalnie, strefę tę tworzyły kontrabanda (głównie $z$ francuskimi i hiszpańskimi posiadłościami na Karaibach i w Ameryce Środkowej) i handel niewolniczy ${ }^{53}$.

$Z$ kolei angielski handel na rynku azjatyckim ciagle był zmonopolizowany w analizowanych latach przez Zjednoczona Kompanię Wschodnioindyjska (United East India Company) działająca za

${ }^{50}$ J. Iliffe, op. cit, s. 155-159; F.W. Pitman, op. cit., s. 271-296. Brytyjscy koloniści emigrowali też na antylskie wyspy będace w posiadaniu innych państw europejskich, gdzie tworzyli wpływowe grupy utrzymujące kontakty $z$ innymi brytyjskimi posiadłościami. Przynosiło to istotne dochody Wielkiej Brytanii. Por. R.B. Sheridan, op. cit., s. 322-328 i 437.

${ }^{51}$ Cyt. za: D.A. Farnie, op. cit., s. 211.

52 Mowa o prawach żeglugowych i handlowych stanowionych od $1650 \mathrm{r}$. Więcej na ten temat por.: L.A. H a r p e r, The English Navigation Laws: A Seventeenth-Century Experiment in Social Engineering, New York 1939, s. 50-62. Por. też C.K. H a r ley, op. cit., vol. I, s. 185; G. Holmes, op. cit., s. 440-441; M. Save1le, The Foundation of American Civilisation. A History of Colonial America, New York 1944, s. 334-346.

${ }^{53} \mathrm{~W}$ największym stopniu tę strefę tworzyli brytyjscy kupcy z Ameryki Północnej i zaangażowani w afrykański handel. Ch.A. Andrews, Colonial Commerce..., s. 55-62; R. Davis, A Commercial Revolution..., s. 20-21; R. Morgan, op. cit., s. 61-63 i 66-67; F.W. Pitman, op. cit., s. 67; R.B. Sheridan, Sugar and Slavery..., s. 319-328; id e m, The Commercial and Financial Organization..., s. $257-258$. 
pośrednictwem faktorii handlowych w Indiach i Chinach (tu jedynie Kanton). Spółce tej udało się przejąć też kontrolę nad handlem w rejonie Zatoki Perskiej54. Kompania dostarczała do Anglii (stąd reeksport do Europy i obu Ameryk) oraz Afryki surowce i gotowe wyroby indyjskiego rękodzielnictwa (jedwab, płótna, perkal, bawełna, dywany, porcelana), artykuły żywnościowe (przyprawy, herbata, kawa) oraz inne drobne towary, jak pachnidła czy saletrę $e^{55}$. W zamian, aby wyrównać ujemny bilans handlowy, Kompania płaciła za import $\mathrm{z}$ rynku azjatyckiego amerykańskimi kruszcami (w ok. 70\%) przekazywanymi przez pośredników w Londynie i Amsterdamie, a niekiedy w Hamburgu lub Kadyksie ${ }^{56}$.

Przedstawiony dynamiczny wzrost angielskiego handlu pozaeuropejskiego w analizowanym okresie 1741-1765 opierał się zatem na stworzonym przez Brytyjczyków globalnym systemie wymiany handlowej łączącej trzy podstawowe rynki angielskiego handlu zewnętrznego: europejski i oceaniczny (atlantycki i azjatycki). Rozwój tego ostatniego i jego strukturę przedstawiają poniższe tabele (od 17 do 21).

${ }^{54}$ W 1708 r. doszło do połaczenia konkurencyjnych spółek związanych z handlem dalekowschodnim w jedna Zjednoczona Kompanię Wschodnioindyjska (The English Company of Trading to the East Indies). J. Kieniewicz, Historia Indii, Wrocław 2004, s. 373; T.O. Lloyd, The British Empire, 1558-1995, Oxford 1996, s. 57; P. S pear, A History of India, vol. II, London 1965, s. 65-69. Jednakże w ramach jej działalności, ale też poza nią, zdaniem niektórych historyków, uaktywnili się w omawianym okresie indywidualni kupcy, zajmujący się przede wszystkim angielskim importem diamentów i innych kruszców. S. Mentz, The English Gentleman Merchant at Work: Madras and the City of London 1660-1740, Copenhagen 2005, s. 119 i 261-276. Natomiast P.J. Marshall, uznany badacz Brytyjskiego Imperium na Wschodzie, całkowicie odrzuca taka indywidualna działalność kupiecka. Id e m, The British in Asia: Trade to Dominion, 1700-1765, [w:] The Oxford History of the British Empire, ed. idem, vol. II (The Eighteenth Century), Oxford 1998, s. 488.

${ }^{55}$ R. Cambe11, op. cit., s. 498. Por. też T.A. Ashton, op. cit., s. 159-160; I. St. John, The Making of the Raj: India under the East India Company, Santa Barbara 2012, s. 68-89; M. Berg, op. cit., s. 99-120.

${ }^{56}$ Ze wspomnianych 1,6 mln \& (wartość napływających do Anglii kruszców $z$ krajów iberyjskich) 1,15 mln $£$ było reeksportowane do Indii Wschodnich i Holandii. A. Attman, op. cit., s. 64-65; T.A. Ashton, op. cit., s. 160; D.C. Coleman, op. cit., s. 142; C.K. Harley, op. cit., vol. I, s. 181. Z rejestrów okrętowych wynika, że porcelana chińska stanowiła prawie $25 \%$ balastu. $Z$ każdymi 100 tonami herbaty przywożono do Europy 6 ton porcelany, co rocznie dawało średnio 240 ton porcelany. H. Hob hou se, Ziarna zmian. Sześć roślin, które zmieniły oblicze świata, Warszawa 2001, s. 186-187. 
Rynki angielskiego handlu pozaeuropejskiego (i kolonialnego) w latach 1741-1765 (w tys. £)

\begin{tabular}{|c|c|c|c|c|c|c|}
\hline \multirow{2}{*}{ Lata } & \multicolumn{3}{|c|}{ Rynek atlantycki } & \multicolumn{3}{c|}{ Rynek azjatycki } \\
\cline { 2 - 7 } & Import & $\begin{array}{c}\text { Eksport/ } \\
\text { reeksport }\end{array}$ & Łacznie & Import & $\begin{array}{c}\text { Eksport/ } \\
\text { reeksport }\end{array}$ & Eacznie \\
\hline $1741-1745$ & 2053 & 1629 & 3682 & 994 & 455 & 1449 \\
\hline $1746-1750$ & 2092 & 1937 & 4029 & 959 & 522 & 1481 \\
\hline $1751-1755$ & 2672 & 2238 & 4910 & 1121 & 787 & 1908 \\
\hline $1756-1760$ & 2684 & 3221 & 5905 & 978 & 817 & 1795 \\
\hline $1761-1765$ & 3710 & 3583 & 7293 & 1102 & 976 & 2078 \\
\hline
\end{tabular}

Źródło: E.B. Schumpeter, English Overseas Trade Statistics, 1697-1808, Oxford 1960, s. 17-18.

Dynamika wzrostu rynków angielskiego handlu pozaeuropejskiego

(i kolonialnego) w latach 1741-1765 (w \%)

\begin{tabular}{|c|c|c|c|c|c|c|}
\hline \multirow{2}{*}{ Lata } & \multicolumn{3}{|c|}{ Rynek atlantycki } & \multicolumn{3}{c|}{ Rynek azjatycki } \\
\cline { 2 - 7 } & Import & $\begin{array}{c}\text { Eksport/ } \\
\text { reeksport }\end{array}$ & Łacznie & Import & $\begin{array}{c}\text { Eksport/ } \\
\text { reeksport }\end{array}$ & Łacznie \\
\hline $1741-1745$ & 100 & 100 & 100 & 100 & 100 & 100 \\
\hline $1746-1750$ & 102 & 119 & 109 & 96 & 115 & 102 \\
\hline $1751-1755$ & 130 & 137 & 133 & 113 & 173 & 132 \\
\hline $1756-1760$ & 131 & 198 & 160 & 98 & 179 & 124 \\
\hline $1761-1765$ & 180 & 220 & 198 & 111 & 214 & 143 \\
\hline
\end{tabular}

Źródło: obliczenia własne na podstawie tabeli 17.

Przedstawione dane wskazuja, że ogólny wzrost angielskiego handlu na rynku atlantyckim wynosił 98\% (przyspieszył zwłaszcza od poczattku lat pięćdziesiatych), w tym importu o $80 \%$ 
(ze stagnacją w okresie 1756-1760 - wzrost o 1\%), a eksportu/ reeksportu o $120 \%$ (tu odmiennie: szczególnie szybki rozwój od lat 1756-1760 - wzrost o 61\%). Jednak ta rosnaca przewaga wywozu nad wwozem nie przełożyła się na stały dodatni bilans handlowy ( $z$ wyjątkiem lat 1756-1760), gdyż przez większość omawianego okresu import zachował prymat pod względem wartości obrotów handlowych.

Tabela 19

Udział poszczególnych rynków w angielskim handlu pozaeuropejskim (w \%)

\begin{tabular}{|c|c|c|c|c|c|}
\hline \multirow{2}{*}{ Lata } & \multirow{2}{*}{$\begin{array}{c}\text { Handel } \\
\text { poza- } \\
\text { europejski }\end{array}$} & \multicolumn{3}{|c|}{ Handel atlantycki } & \multirow{2}{*}{$\begin{array}{c}\text { Handel } \\
\text { azjatycki }\end{array}$} \\
\cline { 3 - 6 } & 100 & 72 & 69 & 3 & 28 \\
\hline $1741-1745$ & 100 & 73 & 69 & 4 & 27 \\
\hline $1746-1750$ & 100 & 72 & 68 & 4 & 28 \\
\hline $1751-1755$ & 100 & 76 & 73 & 3 & 23 \\
\hline $1756-1760$ & 100 & 78 & 73 & 5 & 22 \\
\hline $1761-1765$ & & & & amerykański & \\
\hline
\end{tabular}

Źródło: obliczenia własne na podstawie tabeli 17.

$Z$ kolei analizowane dane informują, że ogólny wzrost angielskiego handlu na rynku azjatyckim wyniósł 43\% i podobnie jak w handlu atlantyckim znaczne przyspieszenie nastapiło od początku lat pięćdziesiątych (wzrost o 30\%). W okresie 1756-1760 przyszedł jednak spadek (o 8\%), by zwyżkować w następnym pięcioleciu (o 19\%). Import na tym rynku odnotował tylko 11\% wzrostu (szczyt wystapił w latach 1751-1755 - 13\%, potem przyszło załamanie w następnym pięcioleciu i powolny rozwój od 1761 r.). Natomiast ogólny progres eksportu/reeksportu wyniósł $114 \%{ }^{57}$, a prawdziwy boom nastał od początku lat pięćdziesiątych (58\% wzrostu), by w latach 1756-1760 wyhamować (tylko 6\% wzrostu) i znów przyspieszyć w następnym pięcioleciu (o 35\%). Powyższe okresowe wahania na rynku

${ }^{57}$ E.B. Schumpeter, op. cit., s. 18. Reeksport stanowił tylko $11 \%$ wywozu do Indii Wschodnich. R. Davis, English Foreign Trade..., s. 300-301. 
azjatyckim zbiegły się $z$ działaniami zbrojnymi brytyjsko-francuskim toczonymi na obu wybrzeżach Indii Wschodnich ${ }^{58}$. Angielski rynek azjatycki, mimo sporej przewagi wzrostu eksportu/reeksportu nad importem, był w jeszcze większym stopniu deficytowy niż rynek atlantycki. Wynikało to ze znacznie większej wartości dóbr importowanych od przywożonych do Indii Wschodnich.

Tabela 20

Rozwój handlu atlantyckiego $z$ uwzględnieniem podziału terytorialnego w latach 1741-1765 (w tys. £)

\begin{tabular}{|c|c|c|c|c|c|c|c|c|c|}
\hline \multirow[b]{2}{*}{ Lata } & \multicolumn{3}{|c|}{ Ameryka Północna } & \multicolumn{3}{|c|}{ Indie Zachodnie } & \multicolumn{3}{|c|}{ Afryka Zachodnia } \\
\hline & $\begin{array}{l}\text { t. } \\
\text { 品 }\end{array}$ & 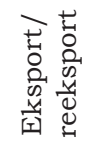 & 㫕 & $\begin{array}{l}\overrightarrow{0} \\
\text { : } \\
\text { 品 }\end{array}$ & 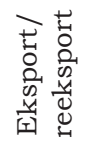 & 㫕 & $\begin{array}{l}\text { t: } \\
\text { : } \\
\text { : }\end{array}$ & 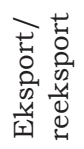 & 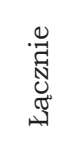 \\
\hline $1741-1745$ & 783 & 771 & 1554 & 1244 & 728 & 1972 & 26 & 130 & 156 \\
\hline $1746-1750$ & 730 & 1025 & 1755 & 1344 & 732 & 2076 & 18 & 180 & 198 \\
\hline $1751-1755$ & 1001 & 1301 & 2302 & 1632 & 710 & 2342 & 39 & 227 & 266 \\
\hline $1756-1760$ & 712 & 2052 & 2764 & 1937 & 952 & 2889 & 35 & 217 & 252 \\
\hline $1761-1765$ & 1066 & 2065 & 3131 & 2614 & 1119 & 3733 & 30 & 399 & 429 \\
\hline
\end{tabular}

Źródło: E.B. Schumpeter, English Overseas Trade Statistics, 1697-1808, Oxford 1960, s. 17-18.

Dane zawarte w tabeli 19 wskazują, że zdecydowaną przewagę $\mathrm{w}$ angielskim handlu pozaeuropejskim utrzymał (w odniesieniu do lat 1715-1740) ${ }^{59}$ rynek atlantycki (ponad 2/3) nad rynkiem azjatyckim. Jednocześnie w analizowanym okresie wzrost udziału $\mathrm{w}$ angielskim handlu oceanicznym odnotował rynek amerykański (od Kanady po Indie Zachodnie), który choć zwyżkował tylko o 4\%, to niemal się pokrywał z całym rynkiem atlantyckim. Można więc mówić o pogłębieniu się procesu amerykanizacji angielskiego handlu oceanicznego (69\% udziału w tej dalekosiężnej wymianie).

${ }^{58}$ Ph. Laws on, The East India Company: A History, London 1993, s. 86-95; P. Spear, op. cit., s. 77-80.

${ }^{59}$ Por. P. Robak, op. cit., s. 63-64. 
Angielski handel $z$ Afryką Zachodnią (od Senegambii po Angolę) stanowił bowiem znikomą część tego rynku (w ujęciu funkcjonalnym bez uwzględnienia handlu niewolniczego), choć w latach 1761-1765 osiagnał wzrost $z$ całym rynkiem atlantyckim.

Tabela 21

Dynamika rozwoju handlu atlantyckiego $z$ uwzględnieniem podziału terytorialnego w latach 1741-1765 (w \%)

\begin{tabular}{|c|c|c|c|c|c|c|c|c|c|}
\hline \multirow[b]{2}{*}{ Lata } & \multicolumn{3}{|c|}{ Ameryka Północna } & \multicolumn{3}{|c|}{ Indie Zachodnie } & \multicolumn{3}{|c|}{ Afryka Zachodnia } \\
\hline & 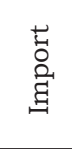 & 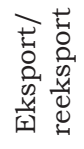 & 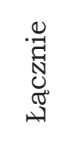 & $\begin{array}{l}\text { 莒 } \\
\text { : } \\
\text { छ्g }\end{array}$ & 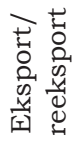 & 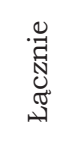 & 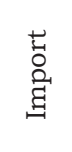 & 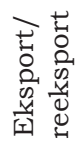 & 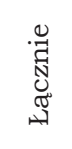 \\
\hline $1741-1745$ & 100 & 100 & 100 & 100 & 100 & 100 & 100 & 100 & 100 \\
\hline $1746-1750$ & 93 & 133 & 113 & 108 & 100 & 105 & 69 & 138 & 127 \\
\hline $1751-1755$ & 128 & 169 & 148 & 131 & 97 & 119 & 150 & 175 & 170 \\
\hline $1756-1760$ & 91 & 266 & 179 & 156 & 131 & 146 & 135 & 167 & 161 \\
\hline $1761-1765$ & 136 & 268 & 201 & 210 & 154 & 189 & 115 & 306 & 275 \\
\hline
\end{tabular}

Źródło: obliczenia własne na podstawie tabeli 20.

Ujęte w tabelach 20-22 dane informują, że pod względem wartości obrotów w strefie handlu atlantyckiego w analizowanych latach 1741-1765 największym rynkiem były Indie Zachodnie ${ }^{60}$. Niemal przez cały ten okres stanowiły bowiem ok. $1 / 2$ angielskiego handlu atlantyckiego (w latach 1746-1760 spadek, potem zwyżka). Ogólny wzrost obrotów handlowych na rynku zachodnioindyjskim wynosił $89 \%$. Istotne przyspieszenie nastapiło w drugiej połowie lat

${ }^{60}$ Był to przede wszystkim monokulturowy rynek produkcji cukru. Najwięcej tego produktu pochodziło $z$ Jamajki ( $1 \frac{1}{2}$ całej produkcji brytyjskiego cukru na Karaibach). Cukier stanowił 89\% eksportu tej wyspy. W latach 1740-1767 nastapił wzrost produkcji cukru na Jamajce $z 17$ tys. ton do 36 tys. ton (Barbados zanotował w tych latach spadek $z 7$ na 6 tys. ton, a inne wyspy produkowały w sumie od 11 do 25 tys. ton). E.B. Schumpeter, op. cit., s. 52-55. Por. też R. Davis, The Rise of Atlantic Economies, London 1973, s. 250-263; R. Pares, War and Trade in the West Indies, Oxford 1936, s. 512-514; R.B. Sheridan, Sugar and Slavery..., s. 217, 437-438 i 448-451. 
pięćdziesiątych i utrzymało się do końca interesującego nas okresu. Rynek ten cechował się też znaczna przewaga importu (wzrost o $110 \%$ ) nad eksportem/reeksportem (wzrost o 54\%), co powodowało stale ujemny bilans angielskiego handlu $z$ „cukrowymi wyspami”. $Z$ kolei rynek północno-amerykański, rozwijajacy się terytorialnie w omawianym okresie, był niewiele mniejszy w skali wartości obrotów handlowych od Indii Zachodnich i w latach 1741-1760 odnotował stopniowy wzrost o 5\%, by w następnym pięcioleciu spaść o $4 \%$. Rynek ten rozwijał się bardziej dynamicznie, gdyż odnotował ogólny wzrost wymiany handlowej o 101\%, jednak wartość wymiany handlowej importu ustępowała zdecydowanie wartości eksportu/reeksportu. Przełożyło się to także na dynamikę wzrostu tych sektorów wymiany, gdyż wywóz zwyżkował 36\%, a wwóz aż 168\%. Był to więc zdecydowanie dla Wielkiej Brytanii rynek proeksportowy $z$ niemal stałym (poza latami 1741-1745) dodatnim bilansem handlowym.

Tabela 22

Udział poszczególnych rynków w angielskim handlu atlantyckim w latach 1741-1765 (w \%)

\begin{tabular}{|c|c|c|c|c|}
\hline Lata & $\begin{array}{c}\text { Handel } \\
\text { atlantycki }\end{array}$ & $\begin{array}{c}\text { Ameryka } \\
\text { Północna }\end{array}$ & $\begin{array}{c}\text { Indie } \\
\text { Zachodnie }\end{array}$ & Afryka \\
\hline $1741-1745$ & 100 & 42 & 54 & 4 \\
\hline $1746-1750$ & 100 & 44 & 51 & 5 \\
\hline $1751-1755$ & 100 & 47 & 48 & 4 \\
\hline $1756-1760$ & 100 & 47 & 49 & 6 \\
\hline $1761-1765$ & 100 & 43 & 51 & 5 \\
\hline
\end{tabular}

Źródło: obliczenia własne na podstawie tabeli 20.

Najmniejszy udział w strefie handlu atlantyckiego pod względem wartości obrotów handlowych miał rynek afrykański. Wynosił on od $4 \%$ do $6 \%$, ale $\mathrm{w}$ omawianym okresie wykazał się największa dynamiką wzrostu, bo sięgająca aż $175 \%$ (spadek o $10 \% \mathrm{w}$ stosunku do lat poprzednich nastapił między 1756 a 1760 r., potem znów zwyżka). Angielski import z Afryki Zachodniej wzrósł o 15\% (ale stały jego spadek w latach 1756-1765 o 36\%), a eksport/reeksport 
aż o 206\% (przy niewielkim procencie spadku w latach 1756-1760, by w następnym pięcioleciu wykazać się nadzwyczajnym wzrostem o 139\%). Rynek afrykański był zatem, podobnie jak północno-amerykański, zdecydowanie proeksportowy w angielskim handlu atlantyckim $z$ wysokim bilansem dodatnim (wwóz stanowił aż 93\% całej atlantyckiej wymiany handlowej w latach 1761-1765).

\section{Podsumowanie}

Uogólniając powyższe rozważania, trzeba podkreślić, że angielski handel zewnętrzny $\mathrm{w}$ analizowanych latach 1741-1765 odnotował ogólny wzrost wartości, jak i dynamiki rozwoju w stosunku do poprzedniego ćwierćwiecza (o 8\%). Ta zwyżkowa tendencja, ale znacznie wyższa procentowo, pojawiła się na niektórych rynkach głównie od połowy XVIII stulecia (na obszarach zamorskich) bądź od okresu 1761-1765 (częściej w Europie). W literaturze przedmiotu to zjawisko określone zostało jako tzw. druga faza „rewolucji handlowej" ${ }^{61}$. Poza tym w rozwoju angielskiego handlu zewnętrznego trwała okazała się również inna tendencja, mianowicie zachowanie dodatniego bilansu handlowego.

Bardziej skomplikowanie sytuacja tego handlu wyglądała w odniesieniu do poszczególnych rynków, co pokazuja poniższe tabele.

Zawarte w tabelach 23-24 dane statystyczne wskazuja, że nadal największy angielski rynek zewnętrzny znajdował się w Europie kontynentalnej, stanowiac w analizowanych latach od $70 \%$ do $62 \%$ (uwidocznił się trwały spadek od lat pięćdziesiątych) całych obrotów zagranicznych. Angielski handel odnotował na tym rynku większy wzrost niż w poprzedzającym go okresie 1715-1740 (o 11\%), w tym zwłaszcza importu (o 17\%), a w mniejszym stopniu eksportu/reeksportu (tylko o $5 \%)^{62}$. Utrzymana została zróżnicowana struktura obrotów na czterech podstawowych rynkach, choć rynek północno-zachodni, ciagle największy pod względem wartości obrotów handlowych, znalazł się w stanie stagnacji (spadek o 10\% tempa rozwoju w stosunku do lat 1715-1740). Z kolei rynek iberyjski, po początkowym wzroście (o tempie porównywalnym do poprzedniego ćwierćwiecza, tj. ponad 60\%), na początku lat sześćdziesiątych odnotował poważny kryzys. Sytuacja na obydwu rynkach stawała się tym bardziej niepokojąca dla perspektyw rozwoju angielskie-

${ }^{61}$ G. Holmes, D. Sechi, op. cit., s. 149.

${ }^{62}$ Dane o tym okresie za: P. Robak, op. cit., s. 54-55. 
go handlu (w tym reeksportu kierowanego na targi niemieckie), że ciagle te dwa rynki utrzymywały pod względem wartości obrotów największy udział w całej tej wymianie, stale zachowujac dodatni bilans handlowy. Do tego dochodził kryzys w handlu lewantyńskim odnotowującym nie tylko okresowe spadki obrotów, lecz także ich niska wartość. Podobna sytuacja wystąpiła w całym angielskim handlu śródziemnomorskim, który choć w zakresie wwozu na rynki państw włoskich przeżywał boom od początku lat sześćdziesiątych, to ogólnie był to handel deficytowy. Natomiast rynek państw północno-wschodnich w strefie nadbałtyckiej kontynuował wzrost wartości obrotów (mimo okresowych wahań), ale jego udział w angielskim handlu europejskim wzrósł tylko do $12 \%$. Poza tym był to także rynek deficytowy, zwłaszcza w odniesieniu do Rosji.

Tabela 23

Udział poszczególnych rynków w angielskim handlu zewnętrznym (w tys. £)

\begin{tabular}{|c|c|c|c|c|c|c|}
\hline \multirow{3}{*}{ Lata } & \multirow{3}{*}{$\begin{array}{l}\text { Handel } \\
\text { ogółem }\end{array}$} & \multirow{3}{*}{$\begin{array}{c}\text { Handel } \\
\text { europejski }\end{array}$} & \multicolumn{4}{|c|}{ Handel pozaeuropejski } \\
\hline & & & \multirow{2}{*}{ ogółem } & \multicolumn{2}{|c|}{ atlantycki } & \multirow{2}{*}{ azjatycki } \\
\hline & & & & amerykański & afrykański & \\
\hline \multirow{2}{*}{$1741-1745$} & \multirow{2}{*}{16661} & \multirow{2}{*}{11530} & \multirow{2}{*}{5131} & \multicolumn{2}{|c|}{3682} & \multirow{2}{*}{1449} \\
\hline & & & & 3526 & 156 & \\
\hline \multirow{2}{*}{$1746-1750$} & \multirow{2}{*}{18376} & \multirow{2}{*}{12866} & \multirow{2}{*}{5510} & \multicolumn{2}{|c|}{4029} & \multirow{2}{*}{1481} \\
\hline & & & & 3831 & 198 & \\
\hline \multirow{2}{*}{$1751-1755$} & \multirow{2}{*}{20918} & \multirow{2}{*}{14100} & \multirow{2}{*}{6818} & \multicolumn{2}{|c|}{4910} & \multirow{2}{*}{1908} \\
\hline & & & & 4644 & 266 & \\
\hline \multirow{2}{*}{$1756-1760$} & \multirow{2}{*}{20478} & \multirow{2}{*}{12778} & \multirow{2}{*}{7700} & \multicolumn{2}{|c|}{5905} & \multirow{2}{*}{1795} \\
\hline & & & & 5653 & 252 & \\
\hline \multirow{2}{*}{$1761-1765$} & \multirow{2}{*}{24461} & \multirow{2}{*}{15090} & \multirow{2}{*}{9371} & \multicolumn{2}{|c|}{7293} & \multirow{2}{*}{2078} \\
\hline & & & & 6864 & 429 & \\
\hline
\end{tabular}

Źródło: E.B. Schumpeter, English Overseas Trade Statistics, 1697-1808, Oxford 1960, s. 17-18.

$\mathrm{Na}$ niepokojacy stan angielskiego handlu na Starym Kontynencie w badanych latach 1741-1765 niewatpliwie miały wpływ toczące się wówczas wojny, zwłaszcza wojna siedmioletnia, i udział w nich Wielkiej Brytanii. Jednak był to wpływ okresowy (najbardziej widoczny w latach 1756-1760), zróżnicowany w odniesieniu do 
struktury obrotów handlowych na poszczególnych rynkach i ograniczony terytorialnie. Nie tłumaczy on więc wszystkich dylematów, jakie stały się udziałem angielskiego handlu w Europie w tym czasie. Wydaje się, że istotną rolę odegrały również inne czynniki, $z$ których najważniejsze to wygasanie traktatów handlowych i przedłużające się negocjacje w zawarciu nowych, a przede wszystkim dość ekspansywna polityka protekcyjna wielu państw, zwłaszcza wprowadzana przez nie w momencie, kiedy angielski handel na Starym Kontynencie odradzał się po zakończeniu wojny w 1763 r.

Tabela 24

Udział poszczególnych rynków w angielskim handlu zewnętrznym (w \%)

\begin{tabular}{|c|c|c|c|c|c|c|}
\hline \multirow{3}{*}{ Lata } & \multirow{3}{*}{$\begin{array}{l}\text { Handel } \\
\text { ogółem }\end{array}$} & \multirow{3}{*}{$\begin{array}{c}\text { Handel } \\
\text { europejski }\end{array}$} & \multicolumn{4}{|c|}{ Handel pozaeuropejski } \\
\hline & & & \multirow{2}{*}{ ogółem } & \multicolumn{2}{|c|}{ atlantycki } & \multirow{2}{*}{ azjatycki } \\
\hline & & & & amerykański & afrykański & \\
\hline \multirow{2}{*}{$1741-1745$} & \multirow{2}{*}{100} & \multirow{2}{*}{69} & \multirow{2}{*}{31} & \multicolumn{2}{|c|}{22} & \multirow{2}{*}{9} \\
\hline & & & & 21 & 1 & \\
\hline \multirow{2}{*}{$1746-1750$} & \multirow{2}{*}{100} & \multirow{2}{*}{70} & \multirow{2}{*}{30} & \multicolumn{2}{|c|}{22} & \multirow{2}{*}{8} \\
\hline & & & & 21 & 1 & \\
\hline \multirow{2}{*}{$1751-1755$} & \multirow{2}{*}{100} & \multirow{2}{*}{68} & \multirow{2}{*}{32} & \multicolumn{2}{|c|}{23} & \multirow{2}{*}{9} \\
\hline & & & & 22 & 1 & \\
\hline \multirow{2}{*}{$1756-1760$} & \multirow{2}{*}{100} & \multirow{2}{*}{62} & \multirow{2}{*}{38} & & & \multirow{2}{*}{9} \\
\hline & & & & 28 & 1 & \\
\hline \multirow{2}{*}{$1761-1765$} & \multirow{2}{*}{100} & \multirow{2}{*}{62} & \multirow{2}{*}{38} & \multicolumn{2}{|c|}{30} & \multirow{2}{*}{8} \\
\hline & & & & 28 & 2 & \\
\hline
\end{tabular}

Źródło: obliczenia własne na podstawie tabeli 23.

Mimo tych wszystkich problemów, jakie dotknęły angielski handel w Europie, przez cały omawiany okres zachował on dodatni bilans handlowy, co w przeważającej mierze było skutkiem rosnącego reeksportu (przeciętnie ok. $1 / 3$ całego wywozu) importowanych towarów zamorskich, w tym zwłaszcza kolonialnych.

$\mathrm{Z}$ kolei angielski handel pozaeuropejski w analizowanych latach 1741-1765, jak wskazuje tabela 24, osiagną wzrost udziału w całym obrocie zewnętrznym od $31 \%$ do $38 \%$ (trwały progres od początku lat pięćdziesiątych). Był to znacznie większy wzrost tego handlu niż 
w poprzednim ćwierćwieczu (o 36\%), zarówno w imporcie (o 25\%), jak i eksporcie/reeksporcie (o $51 \%)^{63}$. Utrzymał się też w tym handlu tradycyjny podział na dwa zasadnicze rynki: atlantycki i azjatycki, funkcjonujacce $\mathrm{w}$ globalnej sieci wymiany $z$ centrum $\mathrm{w}$ metropolii. Jednakże rynek atlantycki osiagnał zdecydowana przewage nad rynkiem azjatyckim, zarówno pod względem wartości obrotów handlowych, jak i ich dynamiki rozwoju (w poprzednich latach 1715-1745 dynamika ta była równa i wynosiła 46\%). Angielski handel na atlantyckim rynku wzrósł od $22 \%$ do $30 \%$ zewnętrznej wymiany. Poza tym, co chyba najważniejsze, handel ten w połowie swej wartości był proeksportowy $z$ zachowaniem dodatniego bilansu handlowego (w Ameryce Północnej i Afryce Zachodniej). Otwierało to obiecujacce perspektywy, biorac pod uwage strukturę towarową tego handlu, przed brytyjska produkcją manufakturowa. Natomiast import $z$ Indii Zachodnich stanowił ważny składnik angielskiego reeksportu, głównie na rynku europejskim, ale docierał też do innych części świata. W tym sensie amerykanizacja angielskiego handlu zewnętrznego nabierała cech globalnych, ale też stawała się istotnym czynnikiem wzrostu gospodarczego Wielkiej Brytanii ${ }^{64}$. W skład atlantyckiego rynku wchodził także angielski handel $z$ Afryką Zachodnią, ale choć dynamicznie się rozwijał (bez uwzględnienia handlu niewolniczego), zwłaszcza w zakresie eksportu/reeksportu i cechował go dodatni bilans handlowy, to ciagłe był to najmniejszy obszar tej wymiany handlowej, wręcz niezauważalny w skali całego angielskiego handlu zewnętrznego (od 1\% do $2 \%$ ).

$Z$ kolei udział rynku azjatyckiego w latach 1741-1765 w całej angielskiej wymianie handlowej utrzymał się na niemal stałym poziomie między $8 \%$ a $9 \%$ (tabela 24 ). Poza tym pozostał on tradycyjnym obszarem monopolu handlowego Kompanii Wschodnioindyjskiej. Zachowując znaczną przewagę importu, cechował się też stałym deficytem wyrównywanym pokaźnym odpływem reeksportowanych kruszców. To jeszcze inna odsłona amerykanizacji angielskiego handlu dalekosiężnego.

${ }^{63}$ Dane za: ibidem, s. 54-55.

${ }^{64} \mathrm{~W}$ opinii brytyjskiego historyka A.H. Johna wojny $z$ lat $1700-1763$ miały korzystny wpływ na rozwój angielskiego przemysłu, zwłaszcza metalowego i stoczniowego, przyniosły wzrost produkcji przemysłowych dóbr konsumpcyjnych, wysoki poziom zatrudnienia i dochodu. Id e m, War and the English Economy, 1700-1763, EcHR 1955, vol. VII, No. 3, s. 344. Więcej na temat dyskusji w anglosaskiej literaturze przedmiotu dotyczacej relacji między rozwojem handlu zewnętrznego a wzrostem gospodarczym Wielkiej Brytanii w XVIII w. por. P. Robak, op. cit., s. 48-49. 
Warto w tym miejscu zwrócić uwagę na jeszcze jedną kwestię. W odróżnieniu od handlu $z$ Europa wspomniane wcześniej wojny, które toczyły się niemal permanentnie na morzach i w koloniach, mimo że w zróżnicowanym stopniu przyniosły okresowe spadki wzrostu na poszczególnych rynkach pozaeuropejskich, to ogólnie nie tylko nie zahamowały rozwoju angielskiego handlu oceanicznego, lecz przyniosły mu także zwłaszcza nowe rynki związane $z$ podbojami terytorialnymi (przynajmniej od $1758 \mathrm{r}$.) ${ }^{65}$. Jedne $z$ nich (wspomniana Hawana, Gwadelupa czy mniejsze wyspy na Antylach) miały charakter czasowy. Inne, usankcjonowane traktatem pokojowym z 1763 r., niosły nowe perspektywy dla angielskiego importu i w znacznie większym stopniu eksportu, ale też handlu niewolniczego, który osiagnął największe rozmiary dopiero $\mathrm{w}$ drugiej połowie XVIII w. ${ }^{66}$

Powyższa sytuację dobitnie wyrażało przekonanie jednego $z$ brytyjskich merkantylistów, Malachy'ego Postlethwayta, zapisane w traktacie Great Britain's True System, etc. (Londyn 1757), że pokój, ze względu na koszty utrzymania kolonii ponoszone przez plantatorów i kupców, jest zdecydowanie bardziej niebezpieczny dla angielskiego handlu niż wojna. Nie pozwala bowiem $z$ powodzeniem rywalizować angielskim towarom $z$ subsydiowanymi przez państwo francuskimi produktami na europejskich rynkach ${ }^{67}$. Podobne poglądy wyrażali także inni ówcześni teoretycy ekonomii politycznej, nie tylko merkantyliści, jak choćby Edmund Burke, upatrując w wojnie i w panowaniu na morzach źródło prosperity handlowej i dobrobytu Wielkiej Brytanii ${ }^{68}$.

65 Zdaniem M.S. Andersona wojny $z$ lat 1739-1763 uczyniły Wielką Brytanię najbardziej dynamiczna siłą imperialna na świecie i pozwoliły jej znacząco rozszerzyć zagraniczny handel. I d e m, op. cit., s. 183. Por. też A.H. J o h n, op. cit., s. 344.

66 J.A. Rawley, op. cit., s. 39; H. Zin s, op. cit., s. 80-81.

67 R.B. Sherid a n, Sugar and Slavery..., s. 434. Por. też P.N. Mille r, Defining the Common Good. Empire, religion and Philosophy in Eighteenth-Century Britain, Cambridge 1994, s. 163.

${ }^{68}$ Edmund Burke wyraził to przekonanie w traktacie The Present State of the Nation (1769). R.B. Sh erid a n, Sugar and Slavery..., s. 452. Na temat poglacdów innych teoretyków rozwoju angielskiego handlu por. D.A. B a u g h t, op. cit., s. 195; P.N. Miller, op. cit., s. 159-163. Co ciekawe, sceptyczni wobec tych zapatrywań pozostali brytyjscy plantatorzy i kupcy związani z antylskim handlem, dla których wojna i podboje terytorialne oznaczały jednak spadek cen cukru. R.B. Sheridan, Sugar and Slavery..., s. 437. 


\section{Bibliografia}

\section{Opracowania}

Anderson M.S., War and Society in Europe of the Old Regime 1618-1789, London 1998.

Andrews Ch.M., Colonial Commerce, „American Historical Review” 1914, vol. XX, No. 1 , s. 45-62.

Antonie M., Louis XV, Paris 1989.

Armitage D., The Ideological Origins of the British Empire, Cambridge 2000.

Aston T.S., An Economic History of England: the $18^{\text {th }}$ Century, London 1955.

Attman A., American Bullion in the European World Trade 1600-1800, Goteborg 1986.

Baugh D.A., Maritime Strenght and Atlantic Commerce. The Uses of „a Grand Marine Empire”, [w:] An Imperial State at War. Britain from 1689 to 1815, ed.

L. Stone, London-New York 1994, s. 185-223.

Berg M., In Pursuit of Luxory: Global History and British Consumer Goods in the Eighteenth Century, „Past and Present” 2004, No. 182, s. 85-142.

Black J., A System of Ambition? British Foreign Policy 1660-1793, Oxford 1991.

Black J, British Diplomats and Diplomacy, 1688-1800, Exeter 2001.

Black J., Natural and Necessary Enemies. Anglo-French Relations in the Eigheenth Century, London 1986.

Bois J.P., De la paix des rois à l'ordre des empereurs 1714-1815, Paris 2003.

Brewer J., The Sinews of Power. War, Money and the English State, 1688-1783, London 1989.

Brinley T., The Industrial Revolution and the Atlantic Economy: Selected Essays, New York 1993.

Brown R., Society and Economy in Modern Britain, 1700-1850, New York 1991.

Butel P., Historie des Antillles françaises XVIIe-XXe siècles, Paris 2007.

Butel P., The Atlantic, London 1999.

Cambell R., The London Tradesman (London 1747), [w:] English Historical Document, vol. IX, eds D.B. Horn, M. Randsome, London 1957.

Christelow A., Great Britain and the Trades from Cadiz and Lizbon to Spanish America and Brazil, 1759-1783, „Hispanic American Historical Review” 1947, vol. XXVII, No. 1.

Coleman D.C., The Economy of England 1450-1750, Oxford 1978.

Conway S., War, State, and Society in Mid-Eighteenth-Century Britain and Ireland, Oxford 2006.

Curtis P., The Atlantic Slave Trade, A Census, Madison 1969.

Davis R., A Commercial Revolution. English Overseas Trade in the Seventeenth and Eighteenth Centuries, London 1967. 
Davis R., English Foreign Trade, 1700-1774, „The Economic History Review” 1962, vol. XV, No. 2, s. 284-303.

Davis R., The Rise of Atlantic Economies, London 1973.

Deane P., The First Industrial Revolution, Cambridge 1969.

Deane P., Cole W.A., British Economic Growth 1688-1959, Cambridge 1967.

Devèzie M., Antillles, Guyannes, la mer des Caraïbes de 1492 à 1789, Paris 1985.

Dunn jr. W.S., Opening New Markets: The British Army and the Old Northwest, Westport 2002.

Eltis D., The Volume and Structure of the Transatlantic Slave trade: A Reassessment, „William and Mary Quarterly” 2001, vol. LVIII, No. 1, s. 17-46.

Engel M., The Economic Development of the Thirteen Continental Colonie, 1720 to 1775, „William and Mary Quarterly” 1975, vol. XXXII, No. 2, s. 191-222.

Farnie D.A., The Commercial Empire of the Atlantic, 1607-1783, „The Economic History Review" 1962, vol. XV, No. 2, s. 205-217.

Ferguson N., Imperium. Jak Wielka Brytania zbudowała nowoczesny świat, Warszawa 2007.

Gierszewski S., Statystyka żeglugi Gdańska w latach 1670-1815, Warszawa 1963.

Harding R., Seapower and Naval Warfare, 1650-1830, London 1999.

Harley C.K., Trade: Discovery, Mercantilism and Technology, [w:] The Cambridge Economic History of Modern Britain, vol. I (Industralisation, 1700-1860), eds R. Floud, P. Johnson, Cambridge 2004, s. 176-203.

Harper L.A., The English Navigation Laws: A Seventeenth-Century Experiment in Social Engineering, New York 1939.

História de Portugal, vol. IV (O Antigo Regime, 1620-1807), ed. D.A.M. Hespanha, Janeiro 1998.

Hobhouse H., Ziarna zmian. Sześć roślin, które zmieniły oblicze świata, Warszawa 2001.

Holmes G., The Making of a Great Power. Late Stuart and Early Georgian Britain, Oxford 1993.

Holmes G., Sechi D., The Age of Oligarchy. Preindustrial Britain 1722-1783, London-New York 1993.

John A.H., War and the English Economy, 1700-1763, „The Economic History Review" 1955, vol. VII, No. 3, s. 329-344.

John St.I., The Making of the Raj: India under the East India Company, Santa Barbara 2012.

Kieniewicz J., Historia Indii, Wrocław 2004.

Knorr K.E., British Colonial Theories 1570-1850, Toronto 1944.

Koehn N.F., The Power of Commerce: Economy and Governance in the First British Empire, Ithaca-New York 1994.

Lawson P., The East India Company: A History, London 1993.

Lloyd T.O., The British Empire, 1558-1995, Oxford 1996.

Magnusom L., Mercantilism: The Shaping of an Economic Language, New York 1994. 
Małowist M., Europa i jej ekspansja XIV-XVII w., Warszawa 1993.

Marshall P.J., The British in Asia: Trade to Dominion, 1700-1765, [w:] The Oxford History of the British Empire, ed. P.J. Marshall, vol. II (The Eighteenth Century), Oxford 1998, s. 487-507.

Maczak A., U źródeł nowoczesnej gospodarki europejskiej, Warszawa 1967.

McKay D., Scott H.M., The Rise of the Great Powers 1648-1815, London-New York 1983.

McNeill J.R., Atlantic Empires of France and Spain: Louisbourg and Havana, 1700-1763, Chapel Hill 1985.

Mémoires du comte de Maurepas, Ministre de la Marine, etc., vol. III, Paris 1792.

Mentz S., The English Gentleman Merchant at Work: Madras and the City of London 1660-1740, Copenhagen 2005.

Miller P.N., Defining the Common Good. Empire, Religion and Philosophy in Eighteenth-Century Britain, Cambridge 1994.

Mitchell B.R., Deane P., Abstract of British Historical Statistics, Cambridge 1962.

Morgan K., Liverpool's Dominance in the British Slave Trade, 1740-1807, [w:] Liverpool and Transatlantic Slavery, eds D. Richardson, S. Schwarz, Liverpool 2007, s. 14-42.

Morgan K., Slavery and the British Empire: from Africa to America, Oxford 2007.

Niedhart G., Handel und Krieg in der Britischen Weltpolitik 1738-1763, München 1979.

Nowak B., Afryka w gospodarce światowej XVI-XVII wieku, [w:] Europa i świat w początkach epoki nowożytnej, cz. 1 (Społeczeństwo, kultura, ekspansja), red.

A. Mączak, Warszawa 1991, s. 301-338.

O'Gorman F., British Political and Social History 1688-1832, London-New York 1997.

Pares R., American versus Continental Warfare, 1739-1763, „English Historical Review" 1936, vol. LI, s. 429-465.

Pares R., War and Trade in the West Indies, Oxford 1936.

Parry J.H., Morskie imperium Hiszpanii, Gdańsk 1983.

Pitman F.W., The Development of the British West Indies, 1700-1763, New Haven 1917.

Pope R., Atlas of British Social and Economic History Since c. 1700, London 1990.

Rawley J.A., London, Metropolis of Slave Trade, Columbia 2003.

Robak P., Angielski handel zewnętrzny (i kolonialny) w latach 1715-1740. Amerykanizacja rynku pozaeuropejskiego, „Przeglad Nauk Historycznych” 2013, R. XII, nr 2, s. 41-70.

Rozbicki M.J., Gospodarka brytyjskiej Ameryki Północnej w XVIII w., [w:] Historia Stanów Zjednoczonych Ameryki, red. M.J. Rozbicki i I. Wawrzyczek, t. I (1607-1763), Warszawa 1995, s. 193-216.

Rutledge J.L., Century of Conflict: The Struggle Between the French and British in Colonial America, New York 1956.

Savelle M., The Diplomatic History of the Canadian Boundary 1749-1763, New Haven-Toronto, 1940.

Savelle M., The Foundation of American Civilisation. A History of Colonial America, New York 1944.

Schumpeter E.B., English Overseas Trade Statistics, 1697-1808, Oxford 1960. 
Sheehan B.W., Wojny imperialne, [w:] Historia Stanów Zjednoczonych Ameryki, red. M.J. Rozbicki i I. Wawrzyczek, t. I (1607-1763), Warszawa 1995, s. 289-322.

Sheridan R.B., The Commercial and Financial Organization of the British Slave Trade, 1750-1807, "The Economic History Review” 1958, vol. XL, No. 2, s. 249-263.

Sheridan R.B., Sugar and Slavery: An Economic History of the British West Indies, 1623-1775, Kingston 1974.

Shlote W., British Overseas Trade from 1700 to the 1930s, Oxford 1952.

Spear P., A History of India, vol. II, London 1965.

Sutton J.L., Wojna o sukcesje polska 1733-1735, Oświęcim 2015.

Szabo F.A.J., Wojna siedmioletnia $w$ Europie 1756-1763, Oświęcim 2014.

Vignol L., L'Asiento français (1701-1713) et anglais (1713-1750) et le commerce franco-espagnol vers 1700 à 1730, „Revue d'Histoire Economique et Sociale” 1929, vol. XVII, No. 3, s. 249-425.

Wieczorkiewicz P., Historia wojen morskich, t. I (Wiek żagla), Londyn 1995.

Williams J.B., British Commercial Policy and Trade Expansion 1750-1850, Oxford 1972.

Zins H., Kupcy i kidnaperzy. Handel niewolnikami $w$ dziejach Afryki i Ameryki, Lublin 1999.

PIOTR ROBAK

\section{English foreign (and colonial) trade during the struggle for Empire (1740-1763)}

Tor he process of Americanisation of overseas trade formed the main ground of colonial rivalries of European states, especially Great Britain and France, in the Atlantic sphere in the first half of the $18^{\text {th }}$ century. This competition caused the series of colonial and naval wars which were connected with European conflicts in the period from 1740 to 1763 . Great Britain took active part in these military events in Europe and in overseas spheres termed in a literature as the struggle for Empire.

The article presented the main directions of a growth of English foreign (and colonial) trade during this stormy period. The English overseas trade statistics (generally based on the collected but approximated date by E.B. Schumpeter) have indicated that in the described years was continued the growth of English foreign trade, especially rapidly from the half of the $18^{\text {th }}$ century what is termed in the contemporary historical literature as a second phase of so called "trade revolution".

This foreign trade was characterized by a dominated position of four traditional European markets with a whole positive balance in all the time. The Northern-Western market (from Germany to Atlantic coast) possessed the biggest and profitable share in this trade but in general scale it was stagnated. On the other hand the trade in the Baltic sphere had a dynamic growth though unprofitable (as a result of a great share of import from Russia). The English trade in Levant was 
in a deep stagnation though it marked a growth in different periods in the commercial exchange with Iberian and Italian states.

The English Extraeuropean trade, however, had a much more dynamic growth than on European markets, though lower in a volume of value and unprofitable in a full scale of its commercial exchange. The main role in this trade played American markets (from Canada to some Caribbean Isles) with some share of Iberoamerican markets in different periods. This part of so called Atlantic economy of England dominated over the whole English Extraeuropean trade. In this Atlantic economy also two markets were profitable: North American and African as important export/reexport spheres, especially for English manufacture goods. Thanks to the great share of overseas import (colonial products) in the English reexport to European markets the whole English foreign trade had the regular positive balance in the described period.

The participation of Great Britain in the mentioned struggle for Empire had many effects to the English foreign (and colonial) trade. These ones were more visibles in Europe than in overseas spheres, in different years, especially during the Seven Years War, with an additional share of political events and a new economic policy (prohibited tarifs) of some states. In contrast to situation in Europe, however, this struggle for Empire conducted at seas and in colonies, in spite of temporary fluctations, encouraged the growth of English overseas trade and brought new colonial markets confirmed by the peace treaty in 1763 .

Keywords: England, foreign trade, colonisation, $18^{\text {th }}$ century. 